\title{
Hybrid poly(ether-arylidene-ether-sulphone)s derivatives for divalent cobalt ion detection
}

\author{
Mahmoud A. Hussein ${ }^{1,2} \cdot$ M. M. Alam ${ }^{3} \cdot K$ Kamal I. Aly $\cdot$ Anish Khan $^{1,4} \cdot$ Hurija Džudžević-Čančar $^{5} \cdot$ Abdullah M. Asiri $^{1,4}$. \\ Mohammed M. Rahman ${ }^{1,4}$
}

Received: 19 December 2019 / Accepted: 14 March 2020 / Published online: 29 March 2020

(c) Springer Nature Switzerland AG 2020

\begin{abstract}
A new set of hybrid poly(ether-arylidene-ether-sulphone)s containing diarylidenecycloalkanone moieties in the polymers main chains has been synthesized in good yields by solution poly-condensation well known polymerization method. The chemical structures of all precursors, monomers and model compound were confirmed by both elemental and spectral data. More particularly, a modified electrode of $\mathrm{Co}^{+2}$ cationic sensor was prepared by the coating of a glassy carbon electrode with synthesized copolymer $\mathbf{8}_{\mathbf{e}}$ as a thin layer. The fabricated cationic sensor was displayed long-term stability, enhanced electrochemical activity, good sensitivity, shorter response time, broad linear dynamic range and lower detection limit. A calibration curve is plotted as current versus concentration of $\mathrm{Co}^{+2}$ ions. The cationic sensor sensitivity is calculated from the slope of calibration curve as $12.8165 \mu \mathrm{AnM}^{-1} \mathrm{~cm}^{-2}$. The detection limit $(0.74 \pm 0.04 \mathrm{nM})$ is also estimated from the signal to noise ratio of 3 . Therefore, the development of $\mathrm{Co}^{+2}$ cationic sensor might be a novel effort with hybrid sulphone polymers by electrochemical method to ensure the sustainability in health care sector.
\end{abstract}

Electronic supplementary material The online version of this article (https://doi.org/10.1007/s42452-020-2528-3) contains supplementary material, which is available to authorized users.

Mahmoud A. Hussein, mahussein74@yahoo.com; maabdo@kau.edu.sa; mahmali@aun.edu.eg; $\bowtie$ Mohammed M. Rahman, mmrahman@kau.edu.sa; mmrahmanh@gmail.com | ${ }^{1}$ Chemistry Department, Faculty of Science, King Abdulaziz University, P.O. Box 80203, Jeddah 21589, Kingdom of Saudi Arabia. ${ }^{2}$ Polymer Chemistry Lab. 122, Chemistry Department, Faculty of Science, Assiut University, Assiut 71516, Egypt. ${ }^{3}$ Department of Chemical Engineering and Polymer Science, Shahjalal University of Science and Technology, Sylhet 3100, Bangladesh. ${ }^{4}$ Center of Excellence for Advanced Materials Research (CEAMR), King Abdulaziz University, P.O. Box 80203, Jeddah 21589, Kingdom of Saudi Arabia. ${ }^{5}$ Department of Natural Science in Pharmacy, Faculty of Pharmacy, University of Sarajevo, Zmaja od Bosne 8, 71000 Sarajevo, Bosnia-Herzegovina. 


\section{Graphic abstract}
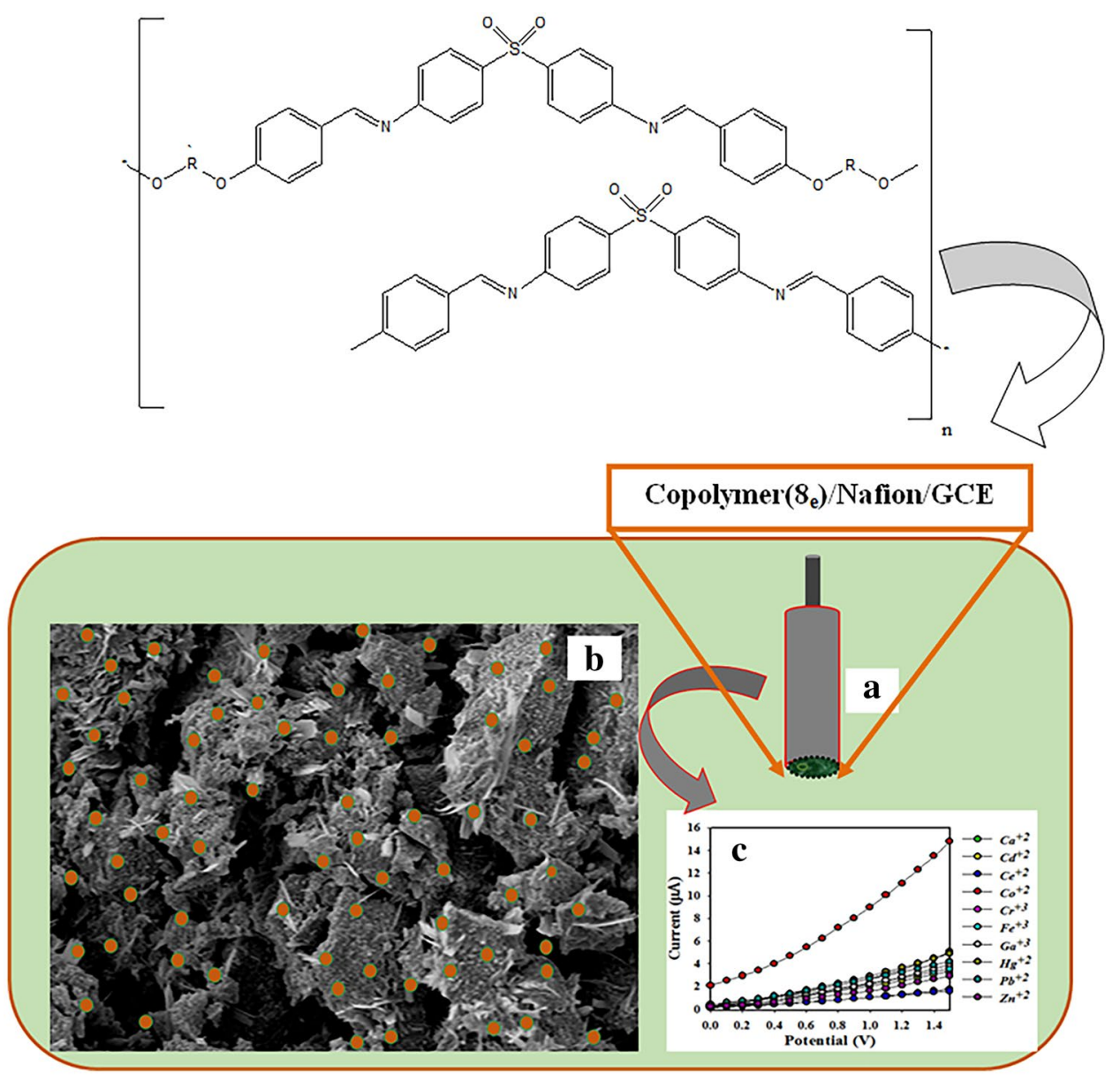

Keywords Poly(ether-arylidene-ether-sulphone)s $\cdot$ Diarylidenecycloalkanones $\cdot$ Thermal behavior $\cdot \mathrm{Co}^{+2} \mathrm{cationic}$ sensor $\cdot$ Sensitivity

\section{Introduction}

Hybrid polymers, are a special class of material, which has been widely used in variable fields of industry and modern technology as well. There are many types of hybrid polymers synthesized worldwide. Each polymer has its specific property which enhance its usage for a particular application. The polymer that shows diverse properties can be used in variable applications. This is only possible if different moieties are attached with a single polymer chain. Therefore, a polymer chain can be modified by adding two or three moieties of different functionalities. The resulting new chain is called hybrid chain which carry the properties of individual as well as extraordinary components. Hybrid polymers and copolymers are a class of macromolecules that can be designed by carrying two or more diverse functional groups. Many hybrid polymers and copolymers have been reported in the past few decades [1-12]. More particularly, hybrid polymers are treated as one of the most widespread types of synthetic macromolecular structures in recent years [13-16]. Arylidene polymers and copolymers are synthetic polymers that can be produced through the formation of arylidene linkage using solution polycondensation technique. Arylidene polymers and copolymers have remarkable properties that can be applied in a variety of industrial applications. Adequate number of polyarylidenes and copolyarylidenes are reported in the literature with excellent conducting ability, surface selectivity, metal uptake ability, thermal stabilities, inhibitive corrosion protection, liquid crystal properties, attractive morphology and biological screening properties [10-12, 17-22]. Similarly, aromatic polyether's are very popular high performance series of synthetic polymers which can be easily prepared through the formation of aryl 
ether linkage as a corner stone in the polymer chain as well as the new ether bond can also be treated as the main polymer formulation response. As reported aromatic nucleophilic substitution reaction is the common procedure that applied for such type of polymerization. Aromatic dihalide molecules invigorated by a high electron deficiency groups, chaired with dihydroxy, in order to form specific polyethers $[23,24]$. The presence of ether bonds into the macromolecular backbone with aromatic substituent renders superior melt processing behaviors, solubility, adhesion, hydrolytic stability, thermal oxidative, high glass transition temperatures, tough mechanical properties as well as liquid crystallinity which may lead them to be applied in micro-electronics and other applications [25-27]. Polyethers also show film production ability for ultrafiltration, gas separation and aerospace vehicles [28]. So far, segmented polyether sulfones are multilateral thermoplastic polymers and copolymers that can be used in industrial engineering due to its unparalleled properties. Polyether sulfones based on aromatic nuclei have been extensively examined due to their high applicability [29-31]. Much more interest expected by the synthesis of separated aromatic polyether sulfone and their copolymers together with other building blocks in the main polymers chain [30, 32]. On the other hand, cobalt is found in soil, sea water, rocks and mineral as a trace amount [33], which is very essential for industries as well as for the biological system. Therefore, a trace amount of cobalt is necessary for many living organism including with human. The metallic cobalt is main component of vitamin B-12 and thiamine [34,35]. With other essential elements, cobalt(II) is also required for human up to few milligram daily [36]. On the other hand, over dose of cobalt(II) metal ion in human body may causes harmful effect such as the damage of heart muscles, over production of red-blood cell and damage of thyroid gland. The deficiency of cobalt(II) ion leads to the retardation of growth, anemia and loss of appetites [37]. So, the optimized quantity of cobalt(II) is essential in human body. In this decade, the consumption of cobalt(II) as raw material is increased remarkably, basically in electrical vehicles and digital components manufacturing industries $[36,38]$. Beside this, cobalt(II) is used extensively in various industries such as nuclear power plant, electroplating, paints, pigments, mining, transformer, generator, and motor [39]. Due to the diversified industrial applications of cobalt(II), there is a great possibility to contaminate the environment with cobalt(II) ions, which released without treating properly. Therefore, it is an urgent necessity to develop a reliable method for $\mathrm{Co}^{+2}$ ion detection in a sustainable way. There are mainly two conventional methods to detect $\mathrm{Co}^{+2}$ ion such as ICP-AES (inductive coupled plasma-atomic emission) [40] and AAS (atomic absorption spectrophotometry) [41]. But these detection methods have disadvantages such as heavy and expensive complex instrumentation, involvement of large infrastructure and backup, low sensitivity and time consuming. Therefore, a method of simple, reliable, high sensitivity, short response time, and portable is desired [42]. On the other hand, the electrochemical method has the best features such as high selectivity, quick response time, inexpensive, and portable [43]. Cobalt(II) ion has both positive and negative impact on human body and now a day, industrial activities with cobalt(II) is increased potentially day by day. Therefore, it very important to develop a reliable method based on electrochemical approaches for the determination of selective cobalt ions. The targeted poly(ether-arylideneether-sulphone)s are one of the most important hybrid polymers which carry a huge number of amazing properties. The designed poly(ether-arylidene-ether-sulphone)s can carry characters of all of its components (polyethers, polyarylidenes as well as polysulphones). Our aim was to design new hybrid applicable in diverse applications. I-V technique in aqueous medium has been utilized to detect the sensing properties of these new hybrid sulphone based polymers against different metal ions. The working electrode of the desire cation sensor has been prepared by deposition of copolymer $\mathbf{8}_{\mathbf{e}}$ (as selected example) as thin layer onto GCE with conducting binder. Then, the projected sensor has been employed to detect $\mathrm{Co}^{+2}$ and it has been exhibited good sensitivity, lower detection limit, a broad linear dynamic range and short response time.

\section{Experimental}

\subsection{Materials, solvents and reagents}

Cycloalkanones including cyclohexanone and cyclopentanone were purchased from Merck (99\% and 99\%) and used as purchased. 4,4'-thioxo-bis(4"-aminophenylene) was purchased from BDH (95\%) was used as purchased. 4-chlorobenzaldehyde was purchased from Fluka (97\%) and was also used as purchased. Vanillin as well as p-hydroxy benzaldehyde were purchased from Merck (95\% and 98\%). Potassium carbonate anhydrous was purchased from Aldrich. Dimethyl sulfoxide was of spectroscopic grade and was purchased from Sigma Aldrich (99\%). To execute this study, the analytical grade chemicals such as Cobalt(II) nitrate, Lead(II) nitrate, gallium(III) nitrate, Zinc sulphate, Chromium(III) chloride, cerium(II) nitrate, calcium(II) chloride, Ferric(III) chloride, Mercury(II) chloride, Cadmium sulphate, disodium phosphate, ammonium hydroxide and monosodium phosphate were used. These chemicals were bought from Sigma-Aldrich Company (USA) and they were used as received. All other chemicals 
and/or reagents were of high purity and they were used as purchased without further purification.

\subsection{Equipments}

Elemental analyses were estimated by an Elemental Anal-

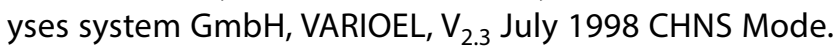
Melting points for all precursors, monomers as well as for model compound were estimated on a Gallen-kamp melting Point apparatus with a digital thermometer type MFB595-010 M. IR spectra were determined on IR-470, Infrared spectrophotometer, Shimadzu using the KBr pellet technique. Mass spectra were investigated on a Joel JMS600 mass spectrometer. ${ }^{1} \mathrm{H}-\mathrm{NMR}$ spectra were carried out on a Varian EM-390-NMR ( $90 \mathrm{MHz}$ ) spectrometer and a GNM-LA 400-MHz NMR spectrophotometer using DMSO or $\mathrm{CDCl}_{3}$ as deuterated solvents and in the presence of TMS as an internal reference. Inherent viscosities were measured by an Ubbelohde suspended level viscometer using $0.5 \% \mathrm{w} / \mathrm{v}$ of polymer and copolymers solutions in DMSO at $30^{\circ} \mathrm{C}$. The $\mathrm{X}$-ray diffraction patterns of the polymers were carried out with a Philips X-ray PW1710 diffractometer, and Ni-filtered CuK $\alpha$ radiations. The molecular weight determination was carried out using GPC gel permeation chromatography using Agilent-GPC Agilent technologies. The refractive index detector was G-1362A with 100-104-105 ^ Altrastyragel columns connected in series. DMF was used as the eluent with flow rate $1.0 \mathrm{~mL} / \mathrm{min}$. PMMA and/or PS standards were of commercial type and were used to calibrate the columns. TGA thermogravimetric analysis and DTG differential thermal gravimetric were obtained in air with TA 2000 thermal analyzer at heating rate of $10^{\circ} \mathrm{C} / \mathrm{min}$. in air. The surface morphology for polymers and copolymers were measured by a SEM scanning electron microscope using a JEOL-JSM-5400 LV-SEM. The SEM sample was prepared by putting a smooth part of polymer powder on a copper holder and then coating it with a gold-palladium alloy. SEM micrographs were picked up using a Pentax Z-50P Camera with Ilford film. The images obtained using a low dose technique at accelerating voltage of $15 \mathrm{kV}$. The Keithley electrometer (6517A, USA) is a simple two electrodes system, which has been implemented to complete the whole experiment of $\mathrm{Co}^{+2}$ ion detection process with fabricated GCE at applied potential of $0 \sim+1.5 \mathrm{~V}$.

\subsection{Synthesis of monomers}

\subsubsection{Synthesis of $4,4^{\prime}$-thioxo-bis $\left(4^{\prime \prime}\right.$-chlorobenzylideneim ino-phenylene) 1}

A mixture of $(2.2 \mathrm{~g}, 0.01 \mathrm{~mol}) 4,4$ 'thioxo-bis(4"aminophenylene) and $1.4 \mathrm{~g}, 0.01 \mathrm{~mol}$ 4-chlorobenzaldehyde were fused together on a hot plate for about 3-4 min, then $20 \mathrm{ml}$ of absolute ethanol was added and refluxed for 4-5 $\mathrm{h}$. The solid product was filtered, washed several times with ethanol, and then recrystallized from DMF as light yellow crystals, m.p $239^{\circ} \mathrm{C}$, yield $65 \%$. Anal. Calcd. for $\mathrm{C}_{26} \mathrm{H}_{18} \mathrm{Cl}_{2} \mathrm{~N}_{2} \mathrm{O}_{2} \mathrm{~S}$ : Calcd.\%: C, 63.28; H, 3.65; N,5.68; S,6.49; $\mathrm{Cl}, 14.40$; Found \%: $\mathrm{C}, 63.80 ; \mathrm{H}, 4.13 ; \mathrm{N}, 5.88 ; \mathrm{S}, 6.22 ; \mathrm{Cl}, 14.64$. IR $(\mathrm{KBr})\left(\mathrm{cm}^{-1}\right): \mathrm{u}=3095(\mathrm{~m}, \mathrm{CH}$ stretching of aromatic), 1620 (s, $\mathrm{C}=\mathrm{N}$ azomethine groups), 1130-1350 (s, sulphone group) and no more absorption bands due to primary amino groups. ${ }^{1} \mathrm{H}-\mathrm{NMR}$ (DMSO- $\left.\mathrm{d}_{6}, \mathrm{ppm}\right): \delta=8.2-7.4(\mathrm{~m}, 16 \mathrm{H}$ aromatic protons), 8.8 ( $\mathrm{s}, 2 \mathrm{H}$ of $\mathrm{N}=\mathrm{CH}$ azomethine bond). Mass spectrum showed a molecular ion peak at $\mathrm{m} / \mathrm{z}=492.1$, 494.2, 493.06 due to $\left(\mathrm{M}^{+}, \mathrm{Cl}=35,100 \%\right) ;\left(\mathrm{M}^{+}, \mathrm{Cl}=37,92.6 \%\right)$, and $\left(\mathrm{M}^{+}, \mathrm{Cl}=35.5,40.5 \%\right)$ respectively which is in agreement with its molecular formula $\left(\mathrm{C} 26 \mathrm{H} 18 \mathrm{Cl} 2 \mathrm{~N}_{2} \mathrm{O}_{2} \mathrm{~S}\right)$. Other peaks were observed at $\mathrm{m} / \mathrm{z}=456.99\left(\mathrm{M}^{+}-\mathrm{Cl}, 4.2 \%\right)$; at $\mathrm{m} / \mathrm{z}=422.7$ $\left(\mathrm{M}^{+}-2 \mathrm{Cl}, 3.2 \%\right)$, at $\mathrm{m} / \mathrm{z}=270.03\left(\mathrm{M}^{+}-\mathrm{C}_{12} \mathrm{H}_{8} \mathrm{Cl}_{2}, 2.7 \%\right)$.

\subsubsection{Synthesis of diarylidenecycloalkanones monomers} $\mathbf{2}_{\mathrm{a}, \mathrm{b}}$ and $\mathbf{3}_{\mathrm{a}, \mathrm{b}}$ their sodium salts $\mathbf{4}_{\mathrm{a}, \mathrm{b}}$ and $\mathbf{5}_{\mathrm{a}, \mathrm{b}}$

Diarylidenecycloalkanones monomers $\mathbf{4}_{\mathbf{a}, \mathbf{b}}$ and $\mathbf{5}_{\mathbf{a}, \mathbf{b}}$ in the form of sodium salts were prepared from their parent premonomers $\mathbf{2}_{\mathbf{a}, \mathbf{b}}$ and $\mathbf{3}_{\mathbf{a}, \mathbf{b}}$ as reported in literature [44, 45]. As well as their chemical structures have been confirmed by elemental and spectral characterization techniques.

\subsection{Synthesis of 4,4'-thioxo-bis(4"-phenoxybenzyli deneiminophenylene) 6}

The title model compound 6 was synthesized by mixing of $(0.98 \mathrm{~g}, 0.002 \mathrm{~mol}) 4,4$ '-thioxo-bis(4"-chlorobenzylide neiminophenylene) $\mathbf{1},(0.464 \mathrm{~g}, 0.004 \mathrm{~mol})$ sodium phenoxide and $(0.50 \mathrm{~g})$ potassium carbonate anhydrous in the presence of $25 \mathrm{ml} \mathrm{DMSO}$ as a reaction solvent. The reaction mixture was heated under vigorous stirring for $12 \mathrm{~h}$ at temperature of $160^{\circ} \mathrm{C}$. The mixture was left to coal to its original temperature, then poured onto ice cold water. The precipitated product was collected by filtration, then washed with water, and crystallized benzene/ethanol as yellowish needles, yield $79 \%$, m.p $>300^{\circ} \mathrm{C}$. Anal. Calcd. for $\mathrm{C}_{38} \mathrm{H}_{28} \mathrm{~N}_{2} \mathrm{O}_{4} \mathrm{~S}$ : Calcd.\%: C, 75.00; H, 4.60; N, 4.60; S, 5.26; Found \%: $\mathrm{C}, 74.79 ; \mathrm{H}, 4.66 ; \mathrm{N}, 4.54 ; \mathrm{S}, 5.33 . \mathrm{IR}(\mathrm{KBr})\left(\mathrm{cm}^{-1}\right)$ : $\mathrm{U}=3085(\mathrm{~m}, \mathrm{CH}$ stretching of aromatic), $1620(\mathrm{~s}, \mathrm{C}=\mathrm{N}$ azomethine groups), 1270 (s, ether bonds), 1135-1350 (s, sulphone group). Mass spectrum exhibited a molecular ion peak at $\mathrm{m} / \mathrm{z}=608.04$ (9.5\%) which is in agreement with its molecular formula $\left(\mathrm{C} 38 \mathrm{H} 28 \mathrm{~N}_{2} \mathrm{O}_{4} \mathrm{~S}\right)$. Other peaks were in accordance with the proposed structure. 


\subsection{Synthesis of polymers $7_{a-d}$}

\section{General procedure}

A mixture of (0.002 mol) 4,4'-thioxo-bis (4'"-chlorobenz ylideneiminophenylene) $\mathbf{1},(0.002 \mathrm{~mol})$ diarylidenecycloalkanones monomers $\mathbf{4}_{\mathrm{a}, \mathrm{b}}$ and $\mathbf{5}_{\mathrm{a}, \mathrm{b}}, 0.50 \mathrm{~g}$ potassium carbonate anhydrous and $30 \mathrm{ml}$ of DMSO was inserted in a three-necked flask installed with a magnetic stirrer and a condenser. The reaction mixture was also carried out in the presence of nitrogen atmosphere. The reaction mixture was heated under vigorous stirring for 10-20 h at temperature of $160^{\circ} \mathrm{C}$. The mixture was left to coal to its original temperature, then poured onto ice cold water. The resulting polymers were separated out by filtration, and washed several times with water and other appreciate solvents. Finally, the products were dried under reduced pressure $(1.0 \mathrm{~mm} / \mathrm{Hg})$ at $80^{\circ} \mathrm{C}$ for 2 days. The following polymers $\mathbf{7}_{\mathbf{a}-\mathbf{d}}$ were synthesized using the overhead mentioned procedure:

\subsubsection{Polymer $7_{a}$}

The titled polymer resulted as brownish powder by the polymerization of $(0.98 \mathrm{~g}, 0.002 \mathrm{~mol}) 4,4^{\prime}$-thioxo-bis $\left(4^{\prime \prime}\right.$ chlorobenzylideneiminophenylene) monomer 1 with $(0.672 \mathrm{~g}, 0.002 \mathrm{~mol})$ monomer $4 \mathrm{a}$ for $20 \mathrm{~h}$, yield $56 \%$. Anal. Calcd. for $\left(\mathrm{C}_{45} \mathrm{H}_{32} \mathrm{~N}_{2} \mathrm{O}_{5} \mathrm{~S}\right)_{n}$ : Calcd \%: $\mathrm{C}, 75.84 ; \mathrm{H}, 4.49 ; \mathrm{N}, 3.93$; $\mathrm{S}, 4.49$; Found \%: $\mathrm{C}, 75.61 ; \mathrm{H}, 4.53 ; \mathrm{N}, 3.99 ; \mathrm{S}, 4.55$. IR (KBr) $\left(\mathrm{cm}^{-1}\right): \mathrm{v}=3030(\mathrm{~m}, \mathrm{CH}$ stretching of aromatic), $2910(\mathrm{~m}$, $\mathrm{CH}$ stretching of aliphatic), 1660 ( $\mathrm{m}, \mathrm{C}=\mathrm{O}$ cyclopentanone), 1610 (s, C=N azomethine groups), 1270 (s, ether bonds), 1125-1340 (s, sulphone group).

\subsubsection{Polymer7}

The titled polymer resulted as brown powder by the polymerization of $(0.98 \mathrm{~g}, 0.002 \mathrm{~mol}) 4,4^{\prime}$-thioxo-bis $\left(4^{\prime \prime}\right.$ chlorobenzylideneiminophenylene) monomer 1 with $(0.792 \mathrm{~g}, 0.002 \mathrm{~mol})$ monomer $\mathbf{4}_{\mathrm{b}}$ for $18 \mathrm{~h}$, yield: $59 \%$. Anal. Calcd. for $\left(\mathrm{C}_{47} \mathrm{H}_{36} \mathrm{~N}_{2} \mathrm{O}_{7} \mathrm{~S}\right)_{n}$ : Calcd \%: $\mathrm{C}, 73.05 ; \mathrm{H}, 4.66 ; \mathrm{N}, 3.62$; $\mathrm{S}, 4.14$; Found \%: $\mathrm{C}, 72.79 ; \mathrm{H}, 4.78 ; \mathrm{N}, 3.77 ; \mathrm{S}, 4.10 . \mathrm{IR}(\mathrm{KBr})$ $\left(\mathrm{cm}^{-1}\right): \mathrm{v}=3030(\mathrm{~m}, \mathrm{CH}$ stretching of aromatic), $2920(\mathrm{~m}$, $\mathrm{CH}$ stretching of aliphatic), 1660 ( $\mathrm{m}, \mathrm{C}=\mathrm{O}$ cyclopentanone), 1610 ( $\mathrm{s}, \mathrm{C}=\mathrm{N}$ azomethine groups), 1250 (s, ether bonds), 1130-1330 (s, sulphone group).

\subsubsection{Polymer $7_{c}$}

The titled polymer resulted as brownish powder by the polymerization of $(0.98 \mathrm{~g}, 0.002 \mathrm{~mol}) 4,4^{\prime}$-thioxo-bis $\left(4^{\prime \prime}\right.$ chlorobenzylideneiminophenylene) monomer 1 with $(0.70 \mathrm{~g}, 0.002 \mathrm{~mol})$ monomer $\mathbf{5} \mathrm{a}$ for $19 \mathrm{~h}$; yield $72 \%$. Anal.
Calcd. for $\left(\mathrm{C}_{46} \mathrm{H}_{34} \mathrm{~N}_{2} \mathrm{O}_{5} \mathrm{~S}\right)_{n}$ : Calcd \%: $\mathrm{C}, 76.03 ; \mathrm{H}, 4.68 ; \mathrm{N}, 3.85$; $\mathrm{S}$, 4.40; Found \%: $\mathrm{C}, 76.93 ; \mathrm{H}, 4.61 ; \mathrm{N}, 3.79 ; \mathrm{S}, 4.46$. IR (KBr) $\left(\mathrm{cm}^{-1}\right): \mathrm{v}=3050(\mathrm{~m}, \mathrm{CH}$ stretching of aromatic), $2910(\mathrm{~m}$, $\mathrm{CH}$ stretching of aliphatic), 1645 ( $\mathrm{m}, \mathrm{C}=\mathrm{O}$ cyclohexanone), 1620 (s, C=N azomethine groups), 1260 (s, ether bonds), $1130-1330$ (s, sulphone group).

\subsubsection{Polymer $\mathbf{7}_{d}$}

The titled polymer resulted as pale-brown powder by the polymerization of $(0.98 \mathrm{~g}, 0.002 \mathrm{~mol}) 4,4^{\prime}$-thioxo-bis $\left(4^{\prime \prime}\right.$ chlorobenzylideneimino-phenylene) monomer 1 with $(0.82 \mathrm{~g}, 0.002 \mathrm{~mol})$ monomer $\mathbf{5}_{\mathbf{b}}$ for $20 \mathrm{~h}$; yield $69 \%$. Anal. Calcd. for $\left(\mathrm{C}_{48} \mathrm{H}_{38} \mathrm{~N}_{2} \mathrm{O}_{7} \mathrm{~S}\right)_{n}$ : Calcd \%: C, 73.28; $\mathrm{H}, 4.83 ; \mathrm{N}, 3.56$; $\mathrm{S}, 4.07$; Found \%: $\mathrm{C}, 73.30 ; \mathrm{H}, 4.85 ; \mathrm{N}, 3.62 ; \mathrm{S}, 3.92 . \mathrm{IR}(\mathrm{KBr})$ $\left(\mathrm{cm}^{-1}\right): \mathrm{v}=3050(\mathrm{~m}, \mathrm{CH}$ stretching of aromatic), $2910(\mathrm{~m}$, $\mathrm{CH}$ stretching of aliphatic), 1645 ( $\mathrm{m}, \mathrm{C}=\mathrm{O}$ cyclohexanone), 1620 (s, C=N azomethine groups), 1270 (s, ether bonds), 1125-1340 (s, sulphone group).

\subsection{Copolymers syntheses $\mathbf{8}_{\mathrm{a}-\mathrm{f}}$}

\section{General procedure}

A mixture of (0.004 mol) 4,4'-thioxo-bis(4"-chlorobenzylid eneiminophenylene) 1, (0.002 mol for each) equal amount from two different diarylidenecycloalkanone monomers $\mathbf{4}_{\mathbf{a}, \mathbf{b}}$ and $\mathbf{5}_{\mathbf{a}, \mathbf{b}}$, potassium carbonate anhydrous and $30 \mathrm{ml}$ of DMSO was inserted in a three-necked flask installed with a magnetic stirrer and a condenser. The reaction mixture was also carried out in the presence of nitrogen atmosphere. The reaction mixture was heated under vigorous stirring for $10-20 \mathrm{~h}$ at temperature of $160^{\circ} \mathrm{C}$. The mixture was left to coal to its original temperature, then poured onto ice cold water. The resulting copolymers were separated out by filtration, and washed several times with water and other appreciate solvents. Finally, the products were dried under reduced pressure $(1 \mathrm{~mm} / \mathrm{Hg})$ at $80^{\circ} \mathrm{C}$ for two days. The following copolymers $\mathbf{8}_{\mathbf{a}-\mathbf{f}}$ were synthesized using the overhead mentioned procedure:

\subsubsection{Copolymer 8}

The titled copolymer resulted as black powder by the copolymerization of $(0.98 \mathrm{~g}, 0.002 \mathrm{~mol}) 4,4^{\prime}$-thioxo-bis $\left(4^{\prime \prime}\right.$ chlorobenzylideneimino-phenylene) monomer 1 with $\left(0.672 \mathrm{~g}\right.$ and $0.792 \mathrm{~g}, 0.002 \mathrm{~mol}$ for each) monomers $\mathbf{4}_{\mathrm{a}}$ and $\mathbf{4}_{\mathbf{b}}$ for $20 \mathrm{~h}$; yield: $59 \%$. Anal. Calcd. for $\left(\mathrm{C}_{92} \mathrm{H}_{68} \mathrm{~N}_{4} \mathrm{O}_{12}\right.$ $\left.\mathrm{S}_{2}\right)_{\mathrm{n}}$ : Calcd \%: C, 74.39; H, 4.58; N, 3.77; S, 4.31; Found \%: $\mathrm{C}, 74.54 ; \mathrm{H}, 4.63 ; \mathrm{N}, 3.79 ; \mathrm{S}, 4.22$. IR (KBr) $\left(\mathrm{cm}^{-1}\right): \mathrm{v}=3050$ ( $\mathrm{m}, \mathrm{CH}$ stretching of aromatic), $2920(\mathrm{~m}, \mathrm{CH}$ stretching of aliphatic), 1645 ( $\mathrm{m}, \mathrm{C}=\mathrm{O}$ cycloalkanone), 1610 (s, C=N 
azomethine groups), 1265 (s, ether bonds), 1125-1330 (s, sulphone group).

\subsubsection{Copolymer $8_{b}$}

The titled copolymer resulted as pale brown powder by the copolymerization of $(0.98 \mathrm{~g}, 0.002 \mathrm{~mol}) 4,4$ '-thioxobis (4"-chlorobenzylideneimino-phenylene) monomer 1 with $(0.672 \mathrm{~g}$ and $0.70 \mathrm{~g}, 0.002 \mathrm{~mol}$ for each) monomers $\mathbf{4}_{\mathrm{a}}$ and $\mathbf{5}$ a for $19 \mathrm{~h}$; yield: $63 \%$. Anal. Calcd. for $\left(\mathrm{C}_{91} \mathrm{H}_{66} \mathrm{~N}_{4} \mathrm{O}_{10} \mathrm{~S}_{2}\right)_{\mathrm{n}}$ : Calcd \%: $\mathrm{C}, 75.93 ; \mathrm{H}, 4.59 ; \mathrm{N}, 3.89 ; \mathrm{S}$, 4.45; Found \%: C, 77.03; $\mathrm{H}, 4.69 ; \mathrm{N}, 3.93 ; \mathrm{S}, 4.35$. IR (KBr) $\left(\mathrm{cm}^{-1}\right): \mathrm{v}=3030(\mathrm{~m}, \mathrm{CH}$ stretching of aromatic), $2920(\mathrm{~m}$, $\mathrm{CH}$ stretching of aliphatic), 1645 ( $\mathrm{m}, \mathrm{C}=\mathrm{O}$ cycloalkanone), 1600 (s, C=N azomethine groups), 1260 (s, ether bonds), 1125-1330 (s, sulphone group).

\subsubsection{Copolymer $\mathbf{8}_{c}$}

The titled copolymer resulted as dark brown powder by the copolymerization of $(0.98 \mathrm{~g}, 0.002 \mathrm{~mol}) 4,4^{\prime}$-thioxobis( 4 "-chlorobenzylideneimino-phenylene) monomer 1 with $(0.672 \mathrm{~g}$ and $0.82 \mathrm{~g}, 0.002 \mathrm{~mol}$ for each) monomers $\mathbf{4}_{\mathbf{a}}$ and $\mathbf{5}_{\mathbf{b}}$ for $19 \mathrm{~h}$; yield: $55 \%$. Anal. Calcd. for $\left(\mathrm{C}_{93} \mathrm{H}_{70} \mathrm{~N}_{4} \mathrm{O}_{12} \mathrm{~S}_{2}\right)_{\mathrm{n}}$ : Calcd \%: C, 74.50; $\mathrm{H}, 4.67 ; \mathrm{N}, 3.73 ; \mathrm{S}$, 4.27; Found \%: $\mathrm{C}, 75.42 ; \mathrm{H}, 4.80 ; \mathrm{N}, 3.79 ; \mathrm{S}, 4.24$. IR (KBr) $\left(\mathrm{cm}^{-1}\right): \mathrm{v}=3030(\mathrm{~m}, \mathrm{CH}$ stretching of aromatic), $2920(\mathrm{~m}$, $\mathrm{CH}$ stretching of aliphatic), 1645 ( $\mathrm{m}, \mathrm{C}=\mathrm{O}$ cycloalkanone), 1610 (s, C=N azomethine groups), 1265 (s, ether bonds), 1120-1340 (s, sulphone group).

\subsubsection{Copolymer $\mathbf{8}_{d}$}

The titled copolymer resulted as black powder by the copolymerization of $(0.98 \mathrm{~g}, 0.002 \mathrm{~mol})$ 4,4'-thioxo-bis (4"chlorobenzylideneimino-phenylene) monomer 1 with ( $0.792 \mathrm{~g}$ and $0.70 \mathrm{~g}, 0.002 \mathrm{~mol}$ for each) monomers $\mathbf{4}_{b}$ and $5_{a}$ for 18 h; yield: $69 \%$. Anal. Calcd. for $\left(\mathrm{C}_{93} \mathrm{H}_{70} \mathrm{~N}_{4} \mathrm{O}_{12} \mathrm{~S}_{2}\right)_{n}$ : Calcd \%: C, 74.50; H, 4.67; N, 3.73; S, 4.27; Found \%: C, 74.43; H, 4.73; N, 3.52; S, 4.26. IR (KBr) $\left(\mathrm{cm}^{-1}\right): \mathrm{U}=3050$ $(\mathrm{m}, \mathrm{CH}$ stretching of aromatic), $2910(\mathrm{~m}, \mathrm{CH}$ stretching of aliphatic), 1660 ( $\mathrm{m}, \mathrm{C}=\mathrm{O}$ cycloalkanone), 1610 (s, C=N azomethine groups), 1260 (s, ether bonds), 1125-1330 (s, sulphone group).

\subsubsection{Copolymer $\mathbf{8}_{\mathrm{e}}$}

The titled copolymer resulted as black powder by the copolymerization of $(0.98 \mathrm{~g}, 0.002 \mathrm{~mol}) 4,4$ '-thioxo-bis (4"'chlorobenzylideneimino-phenylene) monomer 1 with ( $0.792 \mathrm{~g}$ and $0.82 \mathrm{~g}, 0.002 \mathrm{~mol}$ for each) monomers $\mathbf{4}_{\mathrm{b}}$ and $5_{\mathbf{b}}$ for 20 h; yield: $67 \%$. Anal. Calcd. for $\left(\mathrm{C}_{95} \mathrm{H}_{74} \mathrm{~N}_{4} \mathrm{O}_{14} \mathrm{~S}_{2}\right)_{n}$ : Calcd \%: C, 73.17; H, 4.75; N, 3.59; S, 4.10; Found \%: C,
73.77; H, 4.65; N, 3.63; S, 4.16. IR (KBr) $\left(\mathrm{cm}^{-1}\right): \mathrm{v}=3050$ ( $\mathrm{m}, \mathrm{CH}$ stretching of aromatic), $2920(\mathrm{~m}, \mathrm{CH}$ stretching of aliphatic), 1660 ( $\mathrm{m}, \mathrm{C}=\mathrm{O}$ cycloalkanone), 1600 (s, C=N azomethine groups), 1260 (s, ether bonds), 1120-1340 (s, sulphone group).

\subsubsection{Copolymer $\mathbf{8}_{\mathrm{f}}$}

The titled copolymer resulted as brown powder by the copolymerization of $(0.98 \mathrm{~g}, 0.002 \mathrm{~mol}) 4,4^{\prime}$-thioxo-bis (4"chlorobenzylideneimino-phenylene) monomer 1 with ( $0.70 \mathrm{~g}$ and $0.82 \mathrm{~g}, 0.002 \mathrm{~mol}$ for each) monomers $\mathbf{5}_{\mathrm{a}}$ and $\mathbf{5}_{\mathbf{b}}$ for $19 \mathrm{~h}$; yield: $66 \%$. Anal. Calcd. for $\left(\mathrm{C}_{94} \mathrm{H}_{72} \mathrm{~N}_{4} \mathrm{O}_{12} \mathrm{~S}_{2}\right)_{\mathrm{n}}$ : Calcd \%: $C, 74.60 ; \mathrm{H}, 4.76$; N, 3.70; S, 4.23; Found \%: $C$, 74.66; H, 4.62; N, 3.75; S, 4.29. IR (KBr) $\left(\mathrm{cm}^{-1}\right): \mathrm{U}=3030$ (m, CH stretching of aromatic), $2920(\mathrm{~m}, \mathrm{CH}$ stretching of aliphatic), 1645 ( $\mathrm{m}, \mathrm{C}=\mathrm{O}$ cycloalkanone), 1595(s, C=N azomethine groups), 1260 (s, ether bonds), 1125-1340 (s, sulphone group).

2.6.6.1 Fabrication of GCE with hybrid sulphone based polymers The working electrode fabrication process is very important step to success this study. After completing the preparation of these polymers and copolymers, the synthesized copolymer $\mathbf{8}_{\mathbf{e}}$ was used to coat on a GCE with conducting binder as a selected sample. To do this, a slurry of copolymer $\mathbf{8}_{\mathbf{e}}$ was prepared in ethanol and then it was used to deposit on GCE as thin layer. After drying of modified GCE at room condition, a drop of nafion was added on it. Thus, the fabricated electrode was placed inside an oven at $35{ }^{\circ} \mathrm{C}$ for a time necessary to dry the electrode entirely. As a conducting binder, nafion (5\% nafion suspension in ethanol) was used to fabricate the electrode. The using of nafion as conducting binder has various advantages, such as it establishes the binding strength between copolymer $\mathbf{8}_{\mathbf{e}}$ and GCE, which increases the conductivity and electron transfer rate of fabricated electrode in electrochemical sensing performance. A chemical sensor was assembled by Keithley electrometer, where the fabricated electrode (GCE modified with copolymer $\mathbf{8}_{\mathbf{e}}$ and binder) was acted as working electrode and a Pt-wire was as a counter electrode. To perform this study, a number of $\mathrm{Co}^{+2}$ ion solution based on the concentration ranging from $1.0 \mathrm{nM}$ to $0.1 \mathrm{M}$ was prepared and used as target analyte in assembled $\mathrm{Co}^{+2}$ ion sensor. The sensitivity of $\mathrm{Co}^{+2}$ ion sensor was calculated from the slope of the calibration curve (current vs. concentration of $\mathrm{Co}^{+2}$ ion). The linear dynamic rang (LDR) of the projected chemical sensor was calculated from calibration curve at the range, where the regression $\left(r^{2}\right)$ coefficient value is maximum and detection limit was calculated at signal to noise ratio of 3. Amount of $0.1 \mathrm{M}$ PBS-solution was kept constant in 
the beaker as $10.0 \mathrm{~mL}$ throughout the chemical investigation.

\section{Results and discussion}

This research paper aimed to synthesize and characterize a new series of hybrid poly- and copoly(ether-arylideneether-sulphone)s which containing diarylidenecycloalkanone moieties in the polymers essential body. The polymerization reaction was carried out through high temperature polycondensation technique. It was also important to examine all possible characterization techniques. Characterizations based on viscosity, solubility, GPC molecular weight, crystallinity, thermal stability and surface study were investigated and the resulting data were discussed. More particularly, the research aimed to develop a new selective and sensitive fabricated GCE as a $\mathrm{Co}^{+2}$ cationic sensor based on our synthesized hybrid sulphone based polymers by electrochemical approach.

\subsection{Chemistry}

The desired new polymers and copolymers presuppose the synthesis of alternative precursors, monomers and model compound as well. Diphenyl sulphone based monomer named 4,4'-thioxo-bis(4"'-chlorobenzylideneiminophenylene) 1 was synthesized by the interaction of 4,4'-thioxo-bis(4'"-aminophenylene) with 4-chlorobenzaldehyde by fusion for a short period of time and then refluxed in ethanol. The structure of this monomer was elucidated by both elemental and spectral analyses as described in the experimental part (cf. figures S1-S3). Where, the IR spectrum showed a new characteristic absorption peak at $1620 \mathrm{~cm}^{-1}$ which was attributed to the formation of azomethine groups as well as no more bands
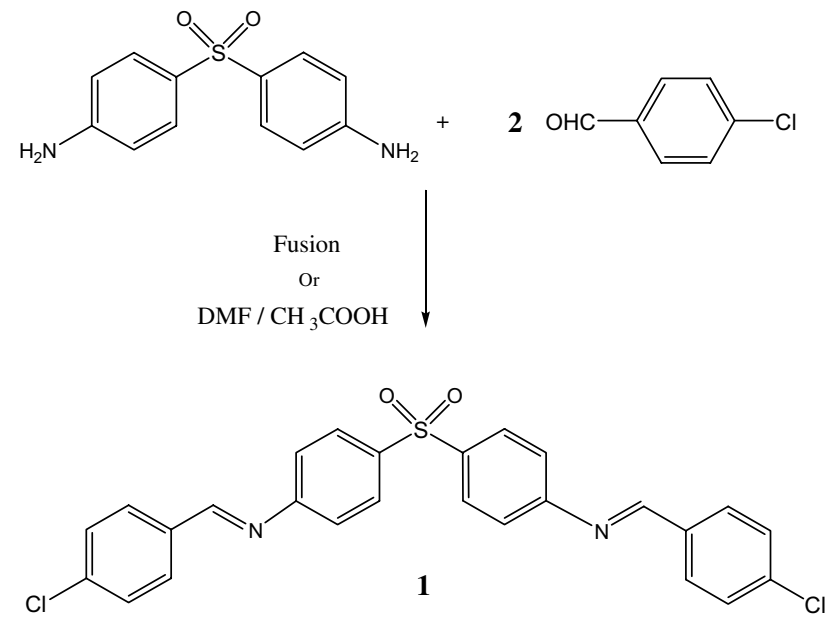

Fig. 1 Synthetic method for thio-ether based monomer 1
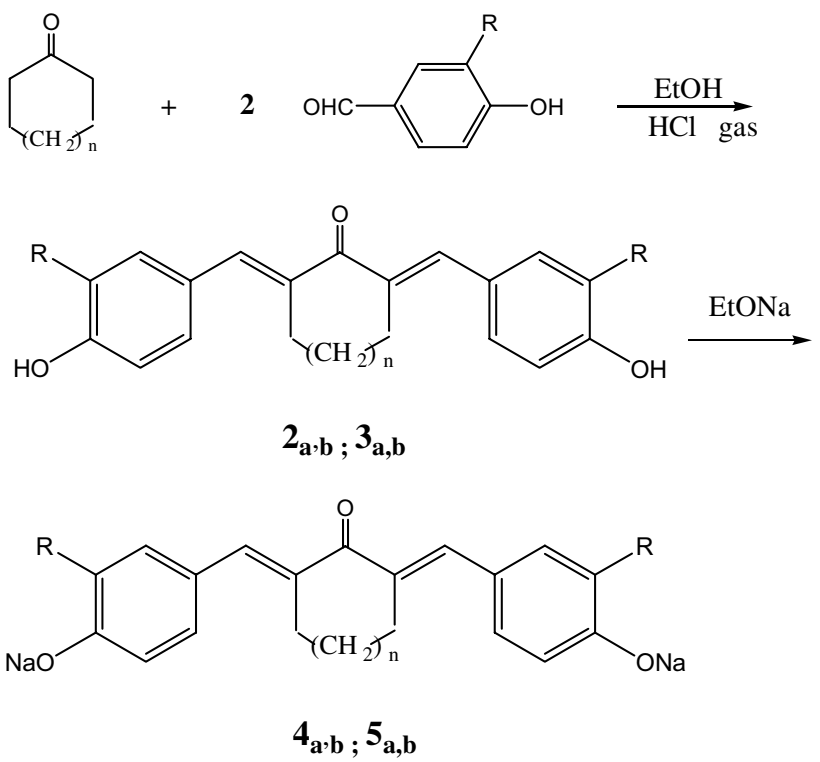

Fig. 2 Synthesis of pre-monomers $\mathbf{2}_{\mathrm{a}, \mathrm{b}}(2 \mathrm{a}, \mathrm{R}=\mathrm{H}, \mathrm{m}=0 ; 2 \mathrm{~b}, \mathrm{R}=\mathrm{H}$, $\mathrm{m}=1$ ) and $\mathbf{3}_{\mathrm{a}, \mathrm{b}}(3 \mathrm{a}, \mathrm{R}=\mathrm{OCH} 3, \mathrm{~m}=0 ; 3 \mathrm{~b}, \mathrm{R}=\mathrm{OCH} 3, \mathrm{~m}=1)$ and diarylidene-cycloalkanone monomers $\mathbf{4}_{\mathrm{a}, \mathrm{b}}(4 \mathrm{a}, \mathrm{R}=\mathrm{H}, \mathrm{m}=0 ; 4 \mathrm{~b}, \mathrm{R}=\mathrm{OCH}$ $3, \mathrm{~m}=0)$ and $\mathbf{5}_{\mathrm{a}, \mathrm{b}}(5 \mathrm{a}, \mathrm{R}=\mathrm{H}, \mathrm{m}=1 ; 5 \mathrm{~b}, \mathrm{R}=\mathrm{OCH} 3, \mathrm{~m}=1)$

for the primary amino groups were found. Furthermore, diarylidenecycloalkanone monomers $\mathbf{4}_{\mathbf{a}, \mathbf{b}}$ and $\mathbf{5}_{\mathbf{a}, \mathbf{b}}$ in the form of sodium salts were prepared from their parent precursors $\mathbf{2}_{\mathbf{a}, \mathbf{b}}$ and $\mathbf{3}_{\mathbf{a}, \mathbf{b}}$ throughout the reaction with sodium ethoxide as estimated in our previous studies $[44,45]$. The structure of these precursors and monomers were elucidated by correct elemental and spectral analyses [44, 45]. Furthermore, the polymerization procedure was tested and checked via model compound 6 preparation. One mole of monomer 1 interacted easily with double moles of sodium phenoxide in DMSO using appropriate amount from anhydrous potassium carbonate as a catalyst. A new absorption band at nearly $1270 \mathrm{~cm}^{-1}$ which was attributed to ether connection was found while checking the IR spectrum. In addition to other characteristic absorption bands which were attributed to other groups are still present. The mass spectrum exhibited a molecular ion peak $(\mathrm{m} / \mathrm{z})$ in accordance with its molecular structure as shown in the experimental part (cf. figures $S 4$ and S5). Figures 1, 2 and 3 showed the schematic diagrams for these recourses, monomers as well as model compound $\mathbf{1}, \mathbf{2}_{\mathbf{a}, \mathbf{b}}$ and $\mathbf{3}_{\mathbf{a}, \mathbf{b}}$ and $\mathbf{4}_{\mathrm{a}, \mathrm{b}}$ and $\mathbf{5}_{\mathrm{a}, \mathrm{b}}$ and $\mathbf{6}$ respectively.

On the other hand, a new series of hybrid poly- and copoly(ether-arylidene-ether-sulphone)s based on diarylidenecycloalkanone moieties in the polymers essential body was synthesized through high temperature polycondensation method [10-12,17, 18, 29-31]. These polymers as well as copolymers were synthesized by the interaction of sulphone based monomer 1 with 
Fig. 3 Synthesis of model compound 6
Fig. 4 Synthesis of poly(etherarylidene-ether-sulphone) s $7_{\text {a-d }}$<smiles>O=S(=O)(c1ccc(/N=C/c2ccc(Cl)cc2)cc1)c1ccc(/N=C/c2ccc(Cl)cc2)cc1</smiles>

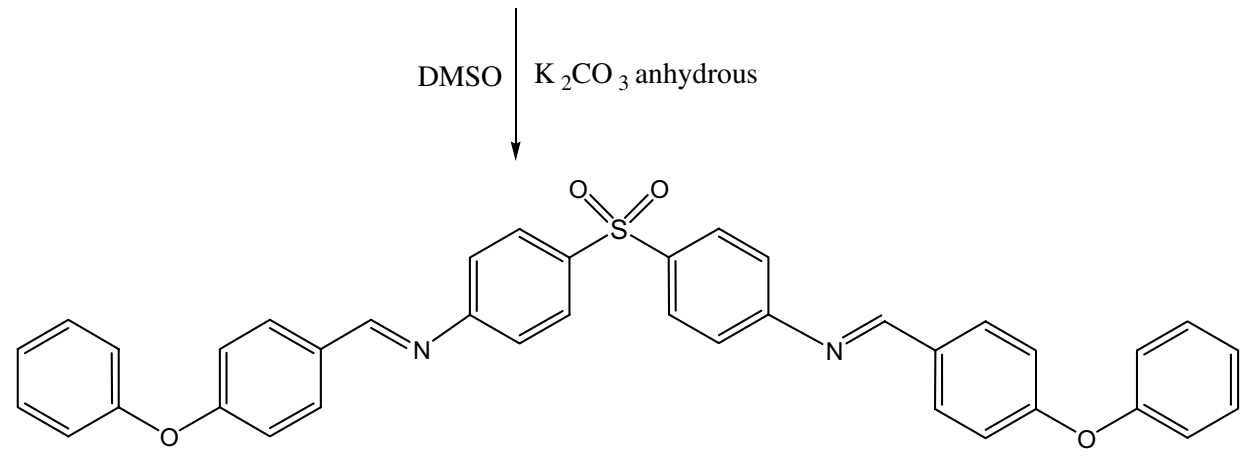

6<smiles></smiles>

Solution Polycondensation

DMSO $/ \mathrm{K}_{2} \mathrm{CO}_{3}$ anhydrous

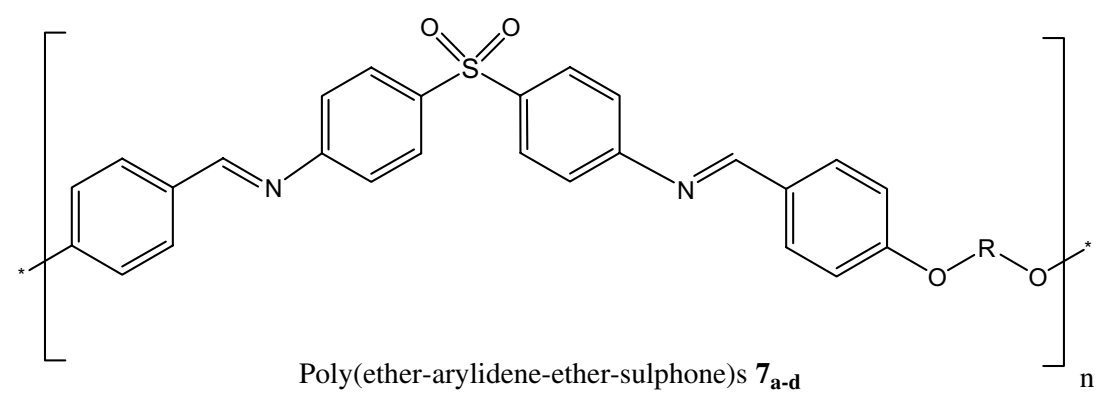

$\mathrm{R}=$

a<smiles>Cc1ccc(/C=C2\CC/C(=C\c3ccc(C)cc3)C2=O)cc1</smiles>

c<smiles>Cc1ccc(C=C2CCCC(=Cc3ccc(C)cc3)C2=O)cc1</smiles>

b<smiles>COc1cc(/C=C2\CC/C(=C\c3ccc(C)c(OC)c3)C2=O)ccc1C</smiles>

d<smiles>COc1cc(/C=C2\CCC/C(=C\c3ccc(C)c(OC)c3)C2=O)ccc1C</smiles> 
Fig. 5 Synthesis of copoly(ether-arylidene-ethersulphone)s $\mathbf{8}_{\text {a-f }}$<smiles>O=S(=O)(c1ccc(/N=C/c2ccc(Cl)cc2)cc1)c1ccc(/N=C/c2ccc(Cl)cc2)cc1</smiles>

$+\mathrm{NaO}-\mathrm{R}-\mathrm{ONa}+\mathrm{NaO}-\mathrm{R}-\mathrm{ONa}$

Solution Polycondensation
$\mathrm{DMSO} / \mathrm{K}_{2} \mathrm{CO}_{3}$ anhydrous

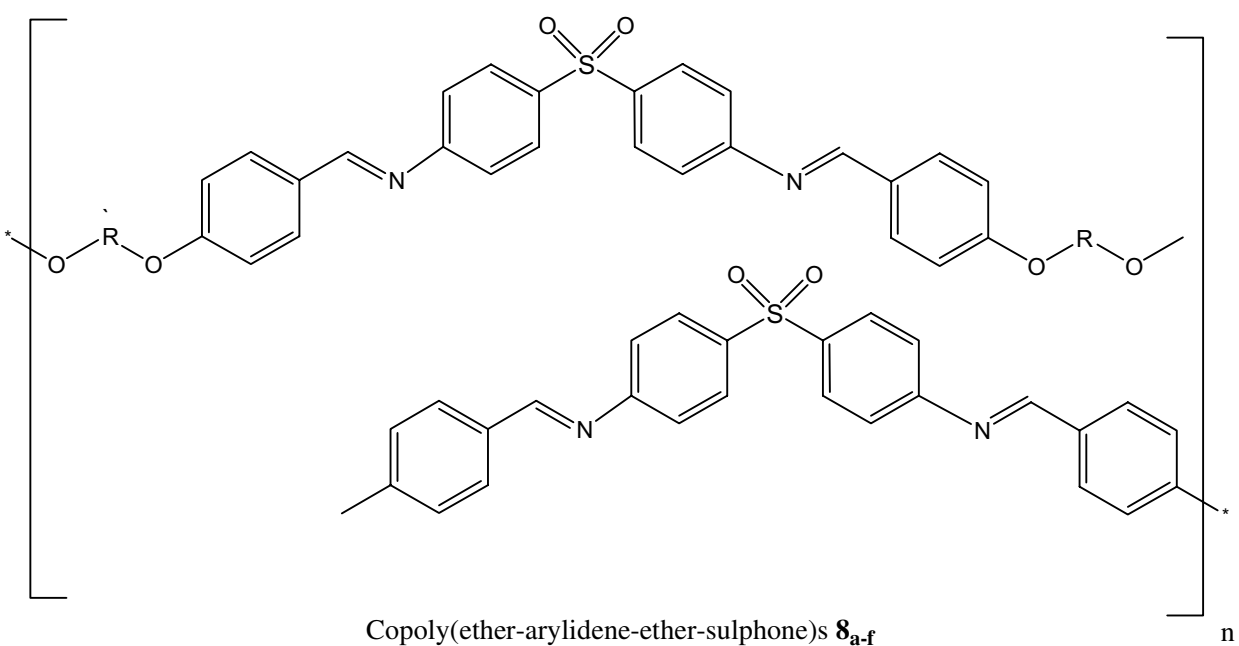

a

Copoly(ether-arylidene-ether-sulphone)s $\mathbf{8}_{\text {a-f }}$<smiles>Cc1ccc(/C=C2\CC/C(=C\c3ccc(C)cc3)C2=O)cc1</smiles><smiles>COc1cc(/C=C2\CC/C(=C\c3ccc(C)c(OC)c3)C2=O)ccc1C</smiles><smiles>Cc1ccc(/C=C2\CC/C(=C\c3ccc(C)cc3)C2=O)cc1</smiles><smiles>Cc1ccc(/C=C2\CCC/C(=C\c3ccc(C)cc3)C2=O)cc1</smiles><smiles>Cc1ccc(/C=C2\CC/C(=C\c3ccc(C)cc3)C2=O)cc1</smiles>

$\mathrm{H}_{3} \mathrm{CO}$<smiles>COc1cc(C=C2CCCC(=Cc3ccc(C)c(OC(C)=O)c3)C2=O)ccc1C</smiles>

d<smiles>COc1cc(/C=C2\CC/C(=C\c3ccc(C)c(OC)c3)C2=O)ccc1C</smiles><smiles>Cc1ccc(/C=C2\CCC/C(=C\c3ccc(C)cc3)C2=O)cc1</smiles>

e<smiles>COc1cc(/C=C2\CC/C(=C\c3ccc(C)c(OC)c3)C2=O)ccc1C</smiles><smiles>COc1cc(/C=C2\CCC/C(=C\c3ccc(C)c(OC)c3)C2=O)ccc1C</smiles>

f<smiles>Cc1ccc(/C=C2\CCC/C(=C\c3ccc(C)cc3)C2=O)cc1</smiles><smiles>COc1cc(/C=C2\CCC/C(=C\c3ccc(C)c(OC)c3)C2=O)ccc1C</smiles> 
Table 1 Solubility characteristics and inherent viscosity of poly(ether-arylidene-ether-sulphone)s $\mathbf{7}_{\mathbf{a}-\mathbf{d}}$ and copoly(ether-arylidene-ethersulphone)s $\mathbf{8}_{\mathrm{a}-\mathrm{f}}$

\begin{tabular}{|c|c|c|c|c|c|c|c|c|c|}
\hline Polymer code & $\begin{array}{l}\text { Chloroform- } \\
\text { acetone mix }\end{array}$ & $\begin{array}{l}\text { Methylene } \\
\text { chloride }\end{array}$ & DMA & THF & DMF & DMSO & Formic acid & Sulfuric acid & $\eta_{i n h}{ }^{*}(\mathrm{dL} / \mathrm{g})$ \\
\hline $7_{a}$ & - & - & + & + & + & + & ++ & ++ & - \\
\hline b & - & - & + & + & + & ++ & ++ & ++ & 0.38 \\
\hline c & + & + & ++ & + & ++ & ++ & ++ & ++ & 0.44 \\
\hline d & + & + & ++ & + & ++ & ++ & ++ & ++ & 0.33 \\
\hline $8_{a}$ & + & - & + & + & ++ & ++ & ++ & ++ & 0.61 \\
\hline b & + & - & ++ & + & ++ & ++ & ++ & ++ & 0.55 \\
\hline c & + & - & ++ & + & ++ & ++ & ++ & ++ & 0.49 \\
\hline d & + & + & ++ & ++ & ++ & ++ & ++ & ++ & 0.70 \\
\hline e & + & + & ++ & ++ & ++ & ++ & ++ & ++ & 0.54 \\
\hline $\mathbf{f}$ & + & + & ++ & ++ & ++ & ++ & ++ & ++ & 0.66 \\
\hline
\end{tabular}

++ : Soluble at room temperature (RT)

+ : Partially soluble at (RT)

-: Insoluble

*: Inherent viscosity was measured in DMSO at $30^{\circ} \mathrm{C}$

diarylidenecycloalkanone monomers $\mathbf{4}_{\mathbf{a}, \mathbf{b}}$ and $\mathbf{5}_{\mathbf{a}, \mathbf{b}}$ in DMSO and in the presence of anhydrous potassium carbonate [44-46]. The schematic diagrams for such polymerization process were illustrated in Figs. 4 and 5 for both polymers and copolymers respectively. The chemical structure of these new polymers and copolymers was confirmed by elemental analyses and spectral data. New bands attributed to carbonyl group of the cycloalkanone moieties were found in the IR spectra as an evidence for the presence of arylidene moieties in the polymers and copolymers main chains. Simultaneously, absorption peaks due to ether new bonds were also observed. Other distinctive peaks which were attributed to the other common functional groups present in the polymers structures for example: azomethine and sulphone groups were also examined (cf. figures $\mathrm{S} 6$ and $\mathrm{S} 7$ as selected examples).

\subsection{Polymers characterizations}

Solubility character of polymers $\mathbf{7}_{\mathbf{a}-\mathbf{d}}$ and copolymers $\mathbf{8}_{\mathbf{a}-\mathbf{f}}$ was determined at room temperature using $0.02 \mathrm{~g}$ of polymer or copolymer sample in 3-5 ml of different solvents. The solubility data were listed in Table 1. Dimethyl sulfoxide, dimethylformamide, tetrahydrofuran, dimethylacetamide, chloroform: acetone mixture $(1: 1 / \mathrm{v}: \mathrm{v})$, methylene chloride, formic and concentrated Sulfuric acid were used as solvents in solubility measurements. The data in Table 1 showed that, all the polymers and copolymers, were completely soluble in $\mathrm{HCOOH}$ and conc. $\mathrm{H}_{2} \mathrm{SO}_{4}$ acids; while they were insoluble in common organic solvents. As it can be also clarified from Table 1, most of the polymers and copolymers were completely soluble in DMSO and DMF
Table 2 GPC molecular weight results for selected polymers and copolymers $\mathbf{7}_{\mathbf{b}, \mathbf{d}}$ and $\mathbf{8}_{\mathbf{b}, \mathbf{d}, \mathbf{f}}$

\begin{tabular}{lcrll}
\hline Polymer code & \multicolumn{4}{l}{${ }^{\mathrm{a} G P C}$} \\
\cline { 2 - 5 } & \multicolumn{1}{l}{${ }^{\mathrm{b}} M_{n}$} & \multicolumn{1}{l}{${ }^{\mathrm{C}} M_{w}$} & ${ }^{\mathrm{d} P D I}$ & ${ }^{\mathrm{f}} P_{w}$ \\
\hline $\mathbf{7}_{\mathbf{b}}$ & $79,061.7$ & $87,467.2$ & 1.106 & $\sim 113$ \\
$\mathbf{d}$ & $73,320.7$ & $82,947.5$ & 1.13 & $\sim 105$ \\
$\mathbf{8}_{\mathbf{b}}$ & $90,705.7$ & $103,427.1$ & 1.14 & $\sim 72$ \\
$\mathbf{d}$ & $102,245.4$ & $116,392.5$ & 1.14 & $\sim 78$ \\
$\mathbf{f}$ & $91,726.8$ & $108,842.6$ & 1.19 & $\sim 72$ \\
\hline
\end{tabular}

${ }^{\text {a } A l l ~ G P C ~ m e a s u r e m e n t s ~ w e r e ~ p e r f o r m e d ~ i n ~ D M F ~}$

${ }^{b}$ number-average molecular weight

'Weight-average molecular weight

${ }^{\mathrm{d}} \mathrm{PDI}=M_{w} / M_{n}$

${ }^{f}$ Average number of repeating units

exclude polymer $\mathbf{7}_{\mathbf{a}}$ and $\mathbf{7}_{\mathbf{a}, \mathbf{b}}$ for both solvents respectively. Furthermore, in THF solvent it was mentioned that, all samples were partially soluble except copolymers $\mathbf{8}_{\mathbf{d}-\mathbf{f}}$ which were easily soluble. Whereas, in DMA all of the copolymers were readily soluble except copolymer $\mathbf{8}_{\mathrm{a}}$ which was partially soluble. More particularly, all the polymers and copolymers were partially soluble or completely insoluble in chloroform: acetone mixture and methylene chloride. The synthesized series was noticeably slightly more soluble in all the selected solvents as compared to other similar series, this was mainly attributed to the presence of sulphone groups together with cyclohexanone moieties in the polymers main chains $[11,12,21,47]$. Furthermore, the solubility character of the synthesized copolymers was slightly higher than the corresponding polymers which 
may be attributed to the presence two cycloalkanone moieties in the polymers backbone compared to the corresponding polymers.

It is well known that polymers molecular weight gives us a real indication about the chain length. Determination of molecular weight was carried out by GPC measurement for selected polymers and copolymers samples $\mathbf{7}_{\mathbf{b}, \mathbf{d}}$ and $\mathbf{8}_{\mathbf{b}, \mathbf{d}, \mathbf{f}}$ and the resulting data were listed in Table 2 . The data in Table 2 showed the average number molecular weight $\left(M_{n}\right)$, the average molecular weight $\left(M_{w}\right)$, PDI (polydispersity index, which represents $\left.M_{w} M_{n}\right)$ and finally the average number of repeating units $\left(P_{w}\right)$ for each sample. A clear look to the data in Table 2 , it was easily to notice that, $M_{n}$ values for the tested samples were in the range 102,245.4-73,320.7; while $M_{n}$ values were ranged from $116,392.5$ to $82,947.5$; so that PDI values were nearly the same $\sim 1.14-1.13$ except for polymer $\mathbf{7}_{\mathbf{b}}$ and $\mathbf{8}_{\mathbf{f}} \sim 1.10$ and 1.19 respectively. Accordingly, the average number of repeating units were in the range 113-72 depending on the estimated molecular weights and theoretical molecular weight values for the repeating units. The resulting average molecular weight for tested polymers was somewhat lower than that observed for the tested copolymers. Polymer $\mathbf{7}_{\mathbf{b}}$ showed the highest average repeating units $P_{w}=\sim 113$; whereas, copolymers $\mathbf{8}_{\mathbf{b}, \mathbf{f}}$ showed the lowest $P_{w}$ values 72 in both cases. By comparing the data for all the selected polymers and copolymers it was found that, copolymer $\mathbf{8}_{\mathbf{d}}$ provide the highest average molecular weight in spite of its average repeating units is low $\left(M_{w}=116,392.5, M_{n}=102,245.4, P_{w}=\sim 78\right.$ and PDI $\left.=1.14\right)$. Whereas, polymer $\mathbf{7}_{\mathrm{d}}$ provide the lowest average molecular weight in spite of its average repeating units still high $\left(M_{w}=82,947.5, M_{n}=73,320.7, P_{w}=\sim 105\right.$ and $\left.\mathrm{PDI}=1.13\right)$.

The inherent viscosity values $\left(\eta_{i n h}\right)$ for polymers $\mathbf{7}_{\mathbf{a}-\mathbf{d}}$, and copolymers $\mathbf{8}_{\mathbf{a}-\mathbf{f}}$ were calculated from the following equation [10-12, 21, 22]:

$\eta_{\text {inh }}=\left[2.3 \log \eta / \eta_{o}\right] / C$

$\eta / \eta_{o}$ represent the viscosity ratio and $C$ represents the sample concentration, almost $0.5 \mathrm{~g} / 100 \mathrm{ml}$ of DMSO was used. The results were also listed in Table 1. Polymer $\mathbf{7 a}$ had no $\eta_{\text {inh }}$ value due to partial soluble indicator. Copolymer $\mathbf{8}_{\mathbf{d}}$ was the highest viscous copolymer compared to the other tested ones, its $\eta_{\text {inh }}$ value was $0.70 \mathrm{dL} / \mathrm{g}$ due to its higher molecular weight value. However, copolymers $\mathbf{8}_{\mathrm{a}, \mathrm{f}}$ still have high $\eta_{\text {inh }}$ values $(0.61 \& 0.66 \mathrm{dL} / \mathrm{g})$ but slightly lower than $\mathbf{8}_{\mathbf{d}}$. Whereas, polymers $\mathbf{7}_{\mathbf{b}, \mathbf{d}}$ were the lowest viscous polymers, their $\eta_{\text {inh }}$ values were $0.38 \mathrm{dL} / \mathrm{g}$ and $0.33 \mathrm{dL} / \mathrm{g}$ respectively. These results were in agreement with that observed from GPC results in the previously mentioned paragraph. The order of higher viscosity for all polymers
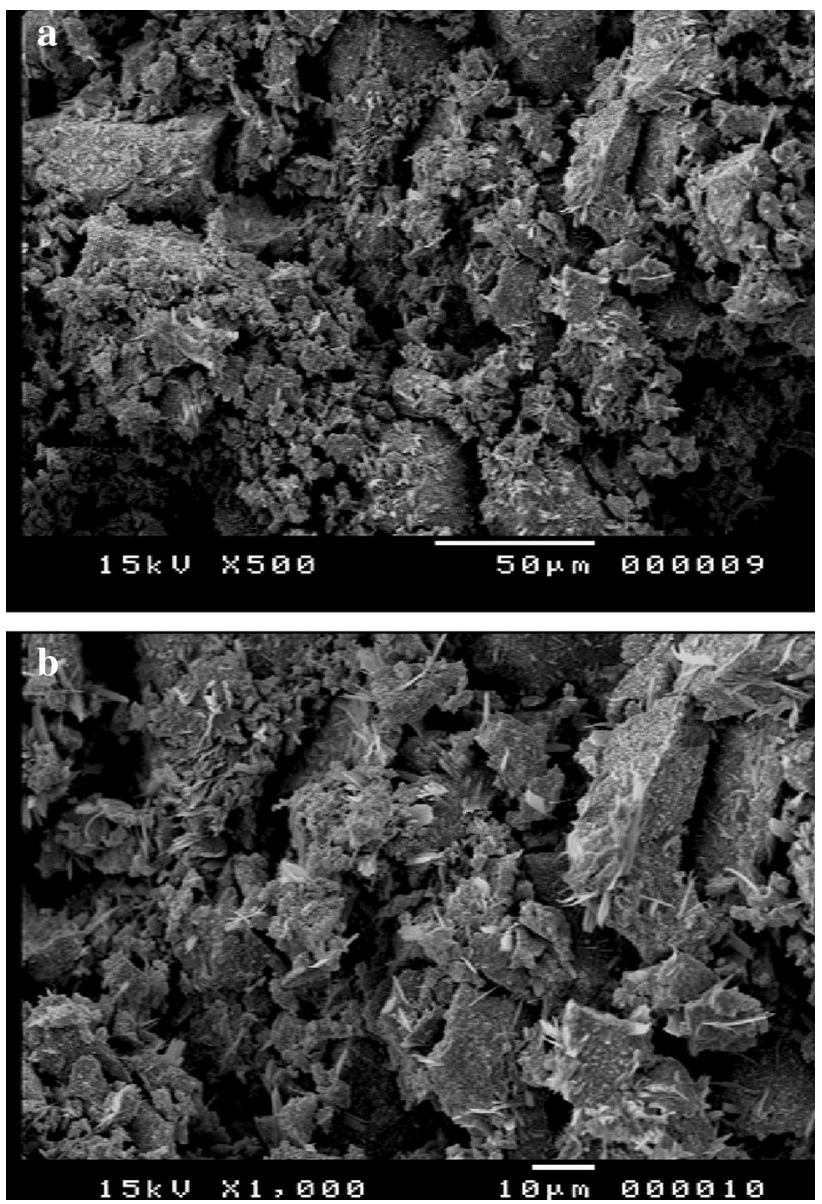

Fig. 6 SEM micrograpgs of polymer $\mathbf{7}_{\mathbf{a}}$ surface at magnifications of $X(a: X=500$ and $b: X=1000)$

and copolymers was $\mathbf{8}_{\mathrm{d}}>\mathbf{8}_{\mathrm{f}}>\mathbf{8}_{\mathrm{a}}>\mathbf{8}_{\mathrm{b} / \mathrm{e}}>\mathbf{8}_{\mathrm{c}}>\mathbf{7}_{\mathrm{c}}>\mathbf{7}_{\mathrm{b}, \mathrm{d}}$, which was also in harmony with GPC consequence.

Figure 6 shows the scanning electron microscopy micrographs of polymer $\mathbf{7}_{\mathbf{a}}$ as selected example. A needles-like aggregates were observed on the surface of polymer $7_{a}$ in both magnifications of $X=500$ and 1000 Figs. $6 a$, $b$ respectively.

Figure 7 illustrated the $\mathrm{X}$-ray diffraction analyses for selected polymers and copolymers $\mathbf{7}_{\mathrm{a}, \mathrm{c}}$ and $\mathbf{8}_{\mathrm{b}, \mathrm{f}}$ in the region $2 \theta=5^{\circ}-60^{\circ}$. The data in Fig. 7 also showed no significant changes in the crystal structures for all tested samples; the crystallographic data were nearly similar. Furthermore, the XRD diffractograms showed high degree of crystallinity in all samples which indicated that these polymers and copolymers were crystalline. This remarks confirm that, there was a major class of structures that were found in the ordered states between crystalline and amorphous phases with respect long-range order in the configuration of their atoms and molecules. As it was reported, the existence of methoxy groups as pendent groups along the polymer backbone decrease the 


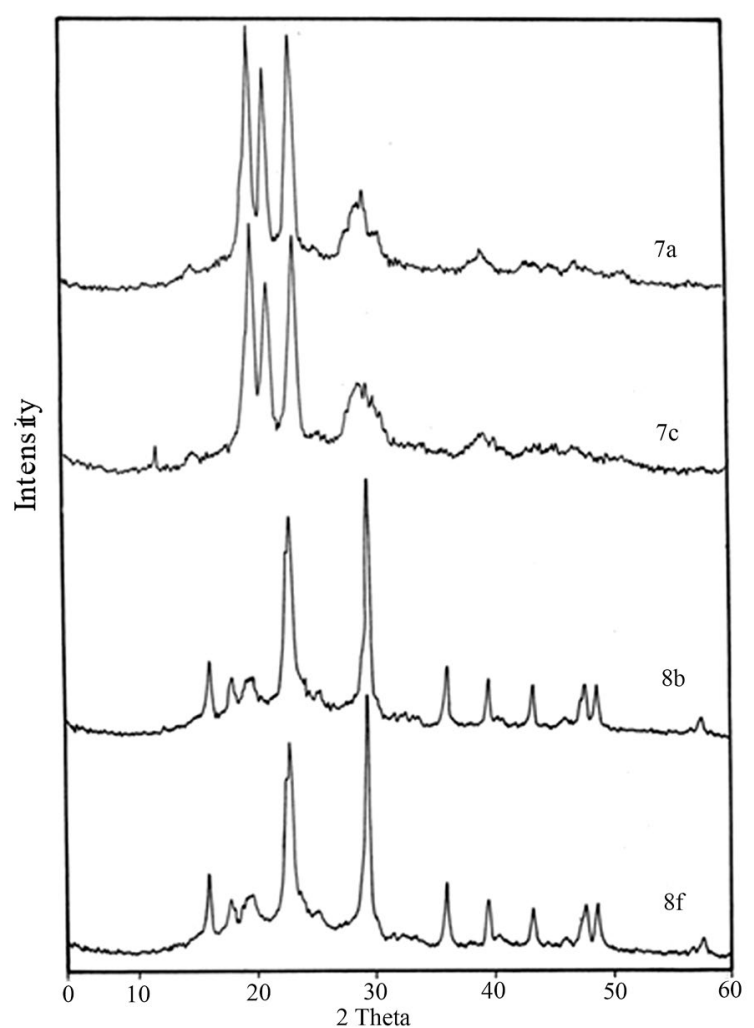

Fig. 7 XRD patterns of poly(ether-arylidene-ether-sulphone)s $\mathbf{7}_{\mathrm{a}, \mathrm{c}}$ and copoly(ether-arylidene-ether-sulphone)s $\mathbf{8}_{\mathbf{b}, \mathbf{f}}$

crystallinity [45]. Whereas, copolymer $\mathbf{8}_{\mathbf{f}}$ showed high crystallinity which may be attributed to the presence of sulphone groups together with cyclohexanone moieties along the polymer chain.

The thermal behavior of polymers is very important character in order to understand the thermal stability and the degradation processes that may occur in our targeted products. TG values were measured from room temperatures up to $750^{\circ} \mathrm{C}$. Table 3 showed the temperatures for diverse percentages of degradations. Temperatures at 10, $20,30,40$ and $50 \%$ of weight losses were determined in the form of $T_{10}, T_{20}, T_{30}, T_{40}$ and $T_{50}$ respectively. No significant decomposition were mentioned before $T_{10}$ in all cases, so that it was treated as polymers degradation temperatures (PDT). PDT values were highly significant which give us good indicator about the thermal stability of this new series. PDT values were appeared in the rang $234-330^{\circ} \mathrm{C}$. Therefore, no considerable decomposition occurs before nearly $300{ }^{\circ} \mathrm{C}$ except for copolymer $\mathbf{8}_{\mathbf{d}}$ that showed $\mathrm{T}_{10}$ at $234^{\circ} \mathrm{C}$. the PDT thermal stabilities of these polymers and copolymers were in the order $\mathbf{7}_{d}>\mathbf{8}_{a}>\mathbf{7}_{b}>\mathbf{8}_{e}>\mathbf{8}_{b}>\mathbf{8}_{d}$. Polymer $\mathbf{8}_{\mathbf{d}}$ showed the lower thermal stability than the others only at $\mathrm{T}_{10}$, while it showed normal thermal behavior at other detected temperatures similar to the others. The polymers decomposed mainly in two steps. The predictable nature of decomposition count on the origin of these polymers and copolymers. The degradation in first step was attributed to a pyrolytic oxidation of carbon-carbon double bonds that come from arylidene moieties followed by cleavage of many other weak bonds. Meanwhile, the prospective nature of degradation in the second step was attributed to cleavage of ether as well as sulphone bonds and scission of many other bonds. At the end, many burnt segment produced as an indicator for the formation of end products. The degradation mechanism was nearly similar to that observed in our previous studies for polymers carry the same groups in their backbones $[10,11,21]$. The extensive weight loss \% (EWL) was referring to the observed weight loss at $600{ }^{\circ} \mathrm{C}$. EWL values were ranged between 29 and $41 \%$ for all tested samples. EWL can go for further decomposition while the temperatures are going to raise up until the formation of end char product at the end of each degradation process. Copolymer $\mathbf{8}_{\mathbf{e}}$ showed the lowest EWL value while polymer $\mathbf{7}_{\mathbf{b}}$ showed the highest value; which was referring to the higher and the lower stability of both products respectively. Copolymers $\mathbf{8}_{\mathbf{d}, \mathbf{e}}$ displayed higher $\mathrm{T}_{40 \%}$ and $\mathrm{T}_{50 \%}$ values than others $\mathrm{T}_{50 \%}$ values (568, 593 and $550,631^{\circ} \mathrm{C}$ ) which was referred to the higher stability of those polymers. While $T_{50 \%}$ values for other samples were nearly comparable and ranged between 560 and $570{ }^{\circ} \mathrm{C}(+2)$. Whereas, polymer $\mathbf{7}_{\mathbf{b}}$ and copolymer $\mathbf{8}_{\mathbf{a}}$ have lower thermally stable values at $\mathrm{T}_{40}$ and $\mathrm{T}_{50}(528,560$ and
Table 3 Thermal properties of poly(ether-arylideneether-sulphone)s $\mathbf{7}_{\mathrm{a}-\mathrm{d}}$ and copoly(ether-arylidene-ethersulphone)s $\mathbf{8}_{\mathrm{a}-\mathrm{f}}$

\begin{tabular}{|c|c|c|c|c|c|c|}
\hline \multirow[t]{2}{*}{ Polymer code } & \multirow[t]{2}{*}{$E W L^{b} \%$} & \multicolumn{5}{|c|}{ Temperature $\left({ }^{\circ} \mathrm{C}\right)$ for various percentage decompositions ${ }^{a}$} \\
\hline & & $10 \%$ & $20 \%$ & $30 \%$ & $40 \%$ & $50 \%$ \\
\hline $\mathbf{7}_{\mathrm{b}}$ & 41 & 318 & 360 & 488 & 528 & 560 \\
\hline d & 36 & 330 & 368 & 502 & 540 & 570 \\
\hline $\mathbf{8}_{\mathbf{a}}$ & 39 & 320 & 427 & 480 & 526 & 562 \\
\hline b & 35 & 296 & 432 & 480 & 540 & 572 \\
\hline d & 32 & 234 & 398 & 470 & 568 & 593 \\
\hline e & 29 & 300 & 415 & 476 & 550 & 631 \\
\hline
\end{tabular}

${ }^{\mathrm{a}}$ The values were determined by TGA at heating rate of $10^{\circ} \mathrm{C} \mathrm{min}^{-1}$

${ }^{\mathrm{b}}$ The values were determined by TGA AT $600{ }^{\circ} \mathrm{C}$ 
$526,562{ }^{\circ} \mathrm{C}$ ) than other products. These results were in a complete harmony with that observed for EWL values.

\subsection{Applications}

\subsubsection{Detection of $\mathrm{Co}^{+2}$ ion by sulphone base copolymers}

The potential application of the proposed cationic sensor based on copolymer $\mathbf{8}_{\mathrm{e}}$ /binder/GCE has been performed to detect selective $\mathrm{Co}^{+2}$ ion in aqueous medium $(\mathrm{pH}=7.0)$. The $\mathrm{Co}^{+2}$ cationic sensor has been exhibited advantages such as stability in air and chemical environment, nontoxicity, enhanced electrochemical activity, simplicity to assemble, inexpensive, very easy to fabricate and above all safe chemo-characteristic. During the successive detection of $\mathrm{Co}^{+2}$ ion in neural buffer medium, the electrochemical response is measured on thin film of copolymer $\mathbf{8}_{\mathbf{e}}$ /binder/ GCE and the holding period of sensing performance has been fixed for $1.0 \mathrm{~s}$ in electrochemical analyzer.

For $\mathrm{Co}^{+2}$ ionic sensor, the resultant current response in electro-chemical method of copolymer $\mathbf{8} \mathbf{e}$ /binder/GCE considerably was changed when aqueous metallic analyte was adsorbed onto the sensor surface. The copolymer $\mathbf{8}_{\mathbf{e}}$ /binder/GCE was applied for fabrication of ionicsensor, where $\mathrm{Co}^{+2}$ ion was measured as target analyte by selectivity study. The fabricated copolymer $\mathbf{8}_{\mathbf{e}} /$ binder/ GCE electrode was placed into the oven at low temperature $\left(30.0^{\circ} \mathrm{C}\right)$ for $2.0 \mathrm{~h}$ to make it dry, stable, and uniform the fabricated-surface totally. Electrochemical signals of $\mathrm{Co}^{+2}$ ionic sensor were anticipated having copolymer $\mathbf{8}_{\mathbf{e}} /$ binder/GCE onto thin-film as a function of current versus potential. A significant amplification in the current response with applied potential was noticeably confirmed during electrochemical investigation at room conditions. Electrochemical characteristic of the copolymer $\mathbf{8} \mathbf{e} /$ binder/ GCE was activated as a function of $\mathrm{Co}^{+2}$ ions concentration at room conditions, where improved current response was presented in Scheme 1 in presence of different analytes including target $\mathrm{Co}^{+2}$. For a low concentration of $\mathrm{Co}^{+2}$ ions in liquid medium, there was a smaller surface coverage of $\mathrm{Co}^{+2}$ ions onto copolymer $\mathbf{8}_{\mathbf{e}}$ /binder/GCE film and hence the surface reaction proceeds steadily. By increasing the target $\mathrm{Co}^{+2}$ ions concentration, the surface reaction was increased significantly (gradually increased the response as well) owing to surface area (assembly of copolymer $\mathbf{8}_{\mathbf{e}}$ ' binder/GCE) contacted with $\mathrm{Co}^{+2}$ ions (Scheme 1a). Further increasing of $\mathrm{Co}^{+2}$ ions onto copolymer $\mathbf{8}_{\mathbf{e}} /$ binder/ GCE sensor surface, it exhibited a more rapid increasing of the current responses, due to larger area covered by $\mathrm{Co}^{+2}$ ions and the interaction of lone-pair of nitrogen, sulfur, and oxygen containing with the functional groups (Scheme 1b). The cation can be adsorbed onto the nitrogen, sulfur, and oxygen sites of the co-polymer chains. Usually, the surface coverage of $\mathrm{Co}^{+2}$ ions on copolymer $\mathbf{8}_{\mathbf{e}}$ /binder/GCE surface was reached to saturation, based on the regular enhancement of current responses with

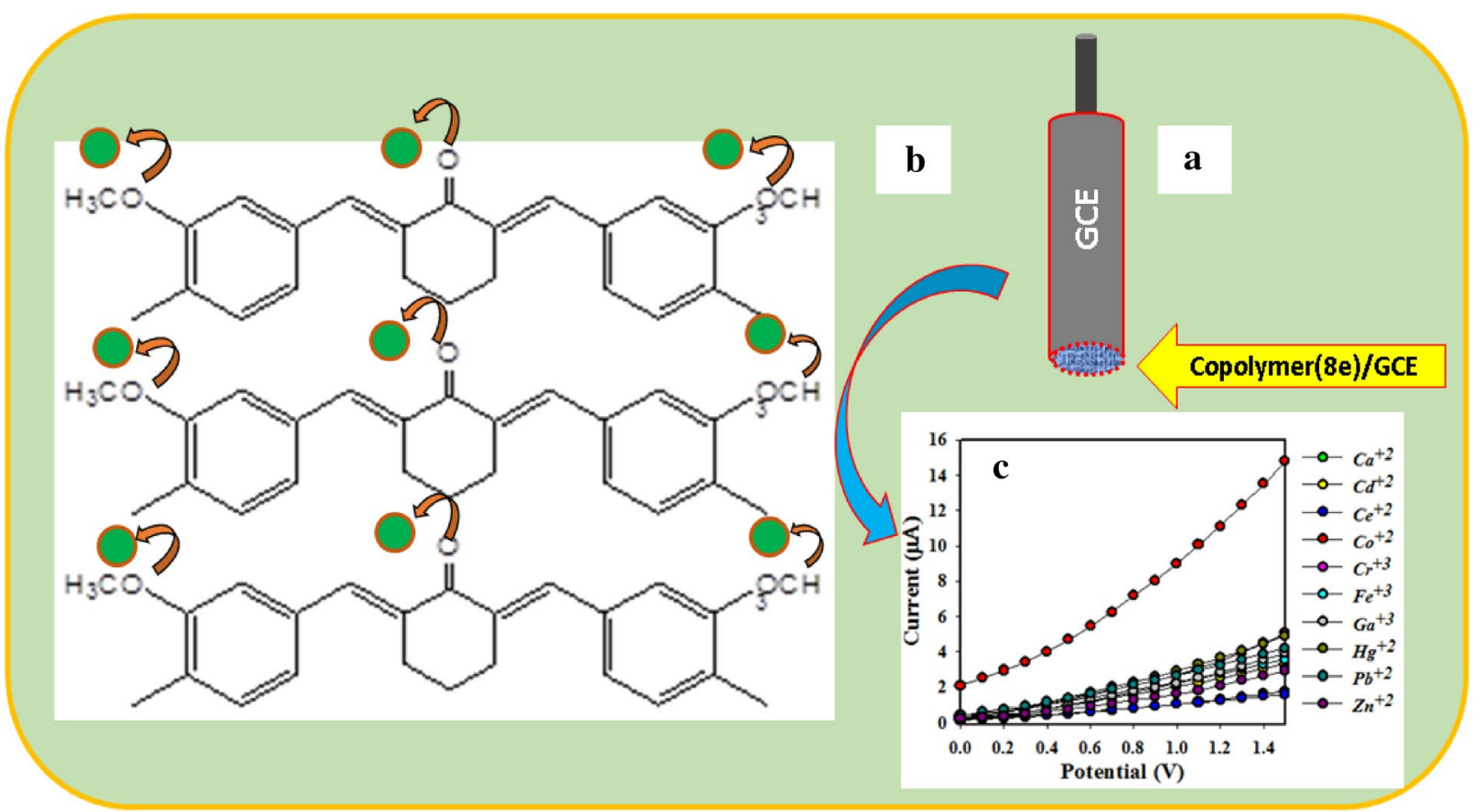

Scheme 1 Mechanism of the probable interaction of $\mathrm{Co}^{+2}$ with copolymer with conducting nafion binders embedded onto GCE. a Fabricated GCE electrode with co-polymer, b adsorption of $\mathrm{Co}^{+2}$ on the copolymer $\mathbf{8}_{\mathbf{e}}$, and $\mathbf{c}$ corresponded current responses in presence of $\mathrm{Co}^{+2}$ ions by electrochemical method 
different analytes, which was shown in Scheme 1c. In the other approach, current-voltage behaviors of the copolymer $\mathbf{8}_{\mathbf{e}}$ were activated as a function of $\mathrm{Co}^{+2}$ ions concentration at room conditions, where improved current response was observed. The possible interaction on bonding mechanism between $\mathrm{Co}^{+2}$ ions and copolymer $\mathbf{8}_{\mathbf{e}}$ was explained in this Scheme 1. As obtained, the current response of the copolymer $\mathbf{8}_{\mathbf{e}}$ fabricated GCE was increased $(\pi-\pi$ as well as $\pi-\pi^{*}$ interaction) with the increasing of $\mathrm{Co}^{+2}$ ionic concentration in the bulk solution, however similar phenomena for toxic chemical detection have also been reported earlier [48-55]. For a low concentration of $\mathrm{Co}^{+2}$ ions in buffer medium, there was a smaller surface coverage of $\mathrm{Co}^{+2}$ ions on copolymer $\mathbf{8}_{\mathrm{e}}$ /binder/GCE and hence the surface reaction proceeds steadily. By increasing the $\mathrm{Co}^{+2}$ ions concentration, the surface reaction was increased significantly (gradually increased the response as well) due to surface area (assembly of copolymer $\mathbf{8} \mathbf{e} /$ binder/GCE) contacted with $\mathrm{Co}^{+2}$ ions molecules. Further increasing of $\mathrm{Co}^{+2}$ ions onto copolymer $\mathbf{8}_{\mathbf{e}} /$ binder/GCE surface, it exhibited the rapid increasing of the resultant current responses. This attributed to larger area is covered by $\mathrm{Co}^{+2}$ ions and the $\pi-\pi$ interaction of the functional groups in copolymer $\mathbf{8}_{\mathbf{e}}$. The $\pi-\pi$ and $\pi-\pi^{*}$ interaction could be approached as inter-molecular and intra-molecular interactions of the copolymer $\mathbf{8}_{\mathbf{e}}$ [56]. Usually, the surface coverage of $\mathrm{Co}^{+2}$ ions on copolymer $\mathbf{8}_{\mathbf{e}} /$ binder/GCE surface was reached to saturation, based on the regular enhancement of current responses.
To estimate the selectivity of the proposed cation sensor, a number of heavy metal ions were considered to investigate by electrochemical method at $0.01 \mu \mathrm{M}$ and $7.0 \mathrm{pH}$. The Fig. 8a was represented such electrochemical responses of $\mathrm{Co}^{+2}, \mathrm{~Pb}^{+2}, \mathrm{Gd}^{+3}, \mathrm{Zn}^{+2}, \mathrm{Cr}^{+3}, \mathrm{Ce}^{+2}, \mathrm{Ca}^{+2}$, $\mathrm{Fe}^{+3}, \mathrm{Hg}^{+2}$, and $\mathrm{Cd}^{+2}$. Obviously, among the heavy metal ions, $\mathrm{Co}^{+2}$ ion has been showed the supreme and intensive electrochemical response. The response time of a chemical sensor was important analytical performance. Thus, the $\mathrm{Co}^{+2}$ cation sensor has been investigated at $0.01 \mu \mathrm{M}$ concentration of $\mathrm{Co}^{+2}$ and $\mathrm{pH}$ of 7.0 to estimate the response time. As it was showed in Fig. $8 \mathrm{~b}$, the steady state electrochemical response has been obtained at around $18.0 \mathrm{~s}$. This value of response time was very good and fast enough to detect the target analyte compared to publish report by Shimizu et al. [57]. The reproducibility was another important criteria to measure the reliability of chemical sensor. The reproducibility test has been executed at $0.01 \mu \mathrm{M}$ concentration of $\mathrm{Co}^{+2}$ and $\mathrm{pH}$ of 7.0. As it was demonstrated in Fig. 8c, the seven replicated run have been executed under the identical condition, but electrochemical responses were indistinguishable and any changes were not found even after washing the electrode in each run. Therefore, it was provided the evidence for reliability of method. The relative standard deviation of the reproducibility was calculated and it was found to be $0.91 \%$. The synthesized copolymer $\mathbf{8}_{\mathbf{e}} /$ binder/GCE sensor probe was not equally active in whole $\mathrm{pH}$ range in the electrochemical solution. Therefore, obtaining the maximum current of
Fig. 8 Optimization of $\mathrm{Co}^{+2}$ ion sensor with sulphone based copolymer a selectivity, b response time, $\mathbf{c}$ reproducibility, $\mathbf{d}$ control experiment, and d $\mathrm{pH}$ effect
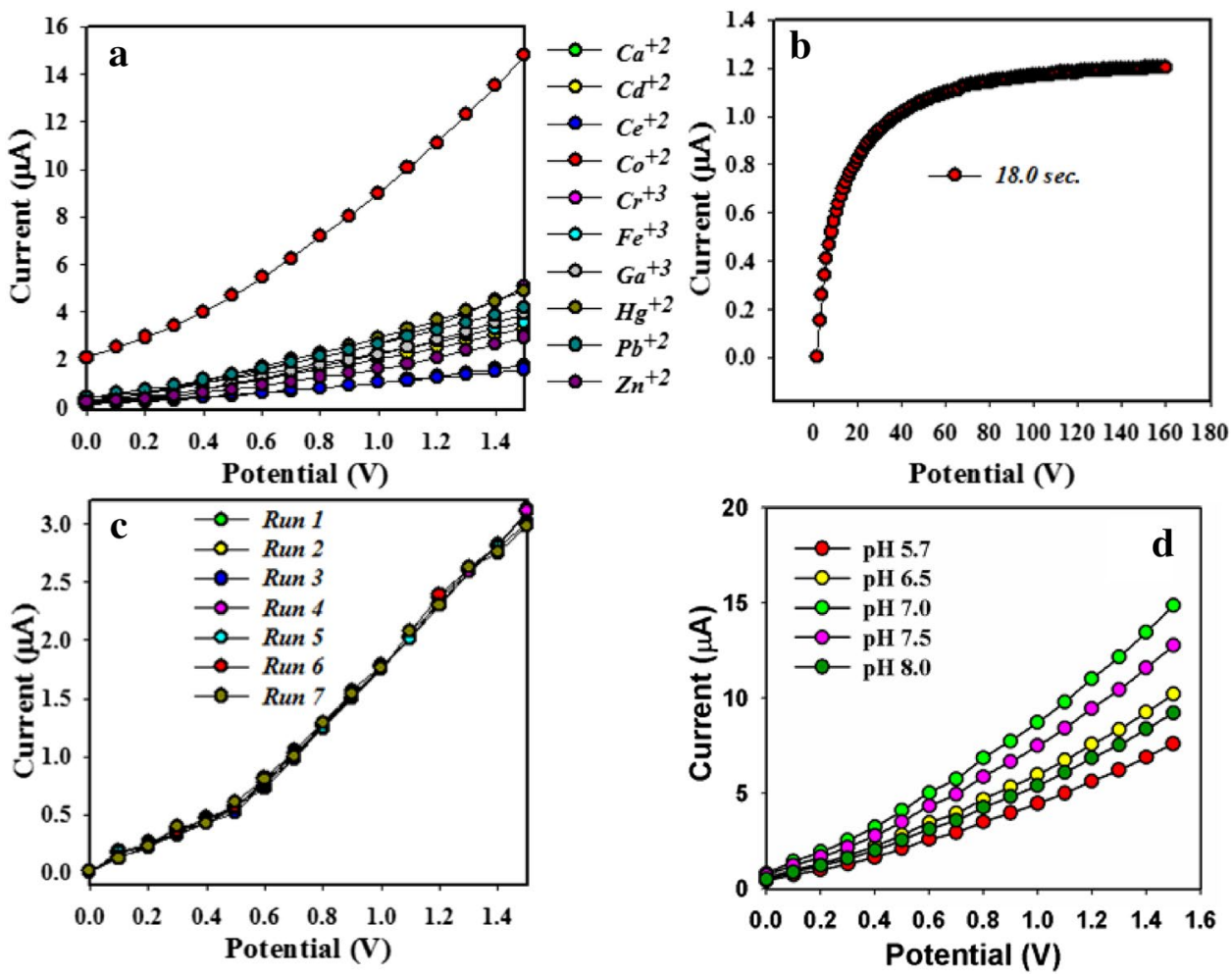
Fig. 9 a Concentration variation of $\mathrm{Co}^{+2}$ cation sensor based on copolymer $\mathbf{8}_{\mathrm{e}}$ / binder/GCE by I-V method and b calibration curve (Inset: log $\left[\mathrm{Co}^{+2}\right.$ ion. Conc.] vs. current)
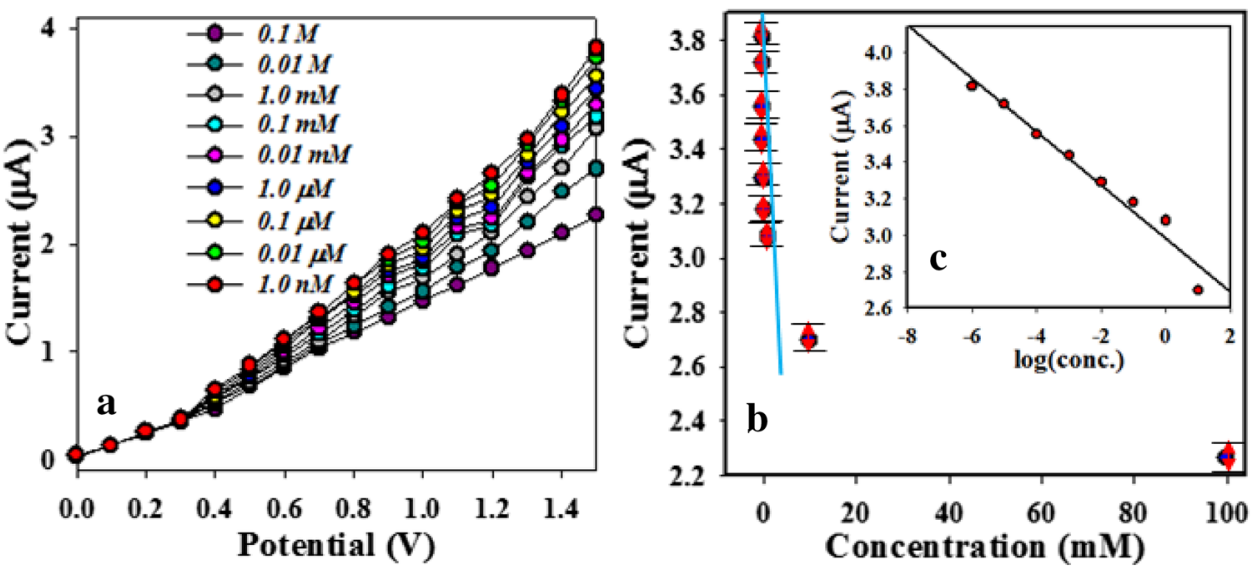

the electrochemical responses, the $\mathrm{pH}$ of the measuring buffer system was necessary to optimize for copolymer $\mathbf{8}_{\mathbf{e}}$ /binder/GCE. Figure $8 \mathrm{~d}$ represents the electrochemical response of $\mathrm{pH}$ ranged from 5.7 to 8.0. Obviously, among the all $\mathrm{pH}$ system, the highest electrochemical response was found at $\mathrm{pH}$ 7.0. Therefore, the rest experiment was carried out at $\mathrm{pH} 7.0$.

The Fig. 9a showed the electrochemical responses of $\mathrm{Co}^{+2}$ ion based on the concentration of $\mathrm{Co}^{+2}$ ranging from $1.0 \mathrm{nM}$ to $0.1 \mathrm{M}$. obviously, this was very wide range of concentration of $\mathrm{Co}^{+2}$ and applied potential was above $+1.0 \mathrm{~V}$. As it was presented in Fig. 9a, the current versus potential (electrochemical) responses were distinguishable from lower to higher concentration of $\mathrm{Co}^{+2}$ ion. A calibration curve (Fig. 9b: current versus concentration of $\mathrm{Co}^{+2}$ ) has been plotted by taking the current data, which were collected from Fig. 9a at applied potential $+1.5 \mathrm{~V}$. The linearity of this plot has been estimated with the concentration axis in logarithmic scale and the linear relationship of plot was found with the regression coefficient $\left(r^{2}=0.9814\right)$. The sensitivity of the proposed $\mathrm{Co}^{+2}$ ion sensor was calculated from the slope of calibration curve by considering the active surface area and it was found to be $12.8165 \mu \mathrm{A} \mathrm{mM}^{-1} \mathrm{~cm}^{-2}$. The linear dynamic range (LDR) was fixed as concentration range of $\mathrm{Co}^{+2}$ ion from the calibration plot. The calibration plot was maximum linear in the range of $1.0 \mathrm{nM}$ to $0.01 \mathrm{M}$. The estimated detection limit (DL) was calculated as $0.74 \pm 0.04 \mathrm{nM}$ at signal to noise ratio of 3 . Thus, it can be noticed that the proposed $\mathrm{Co}^{+2}$ ionic sensor probe would be a reliable to detect selective $\mathrm{Co}^{+2}$ ion by electrochemical method in aqueous medium.

From the Fig. 9a, the electrochemical responses of $\mathrm{Co}^{+2}$ ion was varied with the concentration of $\mathrm{Co}^{+2}$. As it was observed, electrochemical response was exhibited the highest value with the lowest concentration of $\mathrm{Co}^{+2}$ ion. At the time of sensing performance of $\mathrm{Co}^{+2}$ in aqueous medium, electrochemical response was measured on surface of thin-film of fabricated copolymer $\mathbf{8}_{\mathbf{e}} /$ binder/ GCE sensor probe. At the initial of this experiment, the small surface coverage on the working electrode was observed due the adsorption of few of $\mathrm{Co}^{+2}$ ions onto surface of working electrode of proposed cationic sensor and corresponding reaction was started slowly in the beginning. With the increasing of $\mathrm{Co}^{+2}$ cation concentration in sensing medium, the surface coverage by $\mathrm{Co}^{+2}$ ion was also increased. Further, enrichment of $\mathrm{Co}^{+2}$ cation in sensing medium, the corresponding surface coverage was approached to its equilibrium. In this condition, a steady state current density was obtained. The Fig. 9b 
Table 4 Comparison of sensor performances for the detection of selective divalent cobalt ion with on various modified electrodes

\begin{tabular}{|c|c|c|c|c|c|}
\hline Materials & Method & Sensitivity & Detection limit & Response time & References \\
\hline $\begin{array}{l}\text { N2-(bis(pyridin-2-ylmethyl)amino)- } \mathrm{N} \text {-(2- } \\
\text { ((2,4-dinitrophenyl)amino)phenyl) } \\
\text { acetamide }\end{array}$ & Colorimetric & - & $0.99 \mu \mathrm{M}$ & - & {$[48]$} \\
\hline $\begin{array}{l}\text { 2-(N-(2-hydroxybenzyl)-N-((pyridin-2-yl) } \\
\text { methyl)amino)-N-(2-hydroxyphenyl) } \\
\text { acetamide) }\end{array}$ & Colorimetric method & - & $1.8 \mu \mathrm{M}$ & - & [49] \\
\hline $\begin{array}{l}\text { 4-diethylaminosalicylaldehyde-diethyl- } \\
\text { enetriamine }\end{array}$ & Colorimetric method & - & $0.65 \mu \mathrm{M}$ & - & {$[50]$} \\
\hline phthalazine & Chromatography & - & $1.5 \mu \mathrm{M}$ & - & [51] \\
\hline p-(4-n-butylphenylazo)calix [4] arene & Potentiometric titration & - & $4.0 \times 10^{-6} \mathrm{M}$ & $25 \mathrm{~s}$ & [58] \\
\hline Macrocycle compound & Potentiometry & - & - & $20 \mathrm{~s}$ & [59] \\
\hline Coumarin moiety/GCE & Electrochemical method & $19.9146 \mu \mathrm{A} \mu \mathrm{M}^{-1} \mathrm{~cm}^{-2}$ & $94.04 \mathrm{pM}$ & - & [60] \\
\hline CpAD mesoporous silica & Optical method & $185.23 \mathrm{mg} / \mathrm{g}$ & $0.39 \mu \mathrm{g} / \mathrm{L}$ & - & {$[61]$} \\
\hline $\mathrm{P}(\mathrm{Py}-\mathrm{Co}-\mathrm{OT}) / \mathrm{CF} / \mathrm{CS} \mathrm{NCs}$ & Electrochemical method & $16.2848 \mu \mathrm{A} \mu \mathrm{M}^{-1} \mathrm{~cm}^{-2}$ & $94.67 \mathrm{pM}$ & - & {$[62]$} \\
\hline silica based nano-conjugate materials & Optical method & $170.17 \mathrm{mg} / \mathrm{g}$ & $0.33 \mu \mathrm{g} / \mathrm{L}$ & - & {$[63]$} \\
\hline Benzenesulfonohydrazide (BSH)/GCE & Electrochemical method & $1582.3 \mathrm{pA} \mu \mathrm{M}^{-1} \mathrm{~cm}^{-2}$ & $87.6 \mathrm{pM}$ & - & [64] \\
\hline Ce doped $\mathrm{SnO}_{2} \mathrm{NPs} / \mathrm{GCE}$ & ICP-OES & - & - & - & {$[65]$} \\
\hline $\mathrm{Ag}_{2} \mathrm{O}_{3}-\mathrm{ZnO} \mathrm{NCs} / \mathrm{GCE}$ & ICP-OES & $76.69 \mathrm{mg} \mathrm{g}^{-1}$ & - & - & {$[66]$} \\
\hline EBDMBS/GCE & Electrochemical method & $1.87 \mu \mathrm{A} \mu \mathrm{M}^{-1} \mathrm{~cm}^{-2}$ & $0.17 \mathrm{nM}$ & - & {$[67]$} \\
\hline Copolymer(8e)/binder/GCE & Electrochemical method & $12.8165 \mu \mathrm{AnM}^{-1} \mathrm{~cm}^{-2}$ & $0.74 \pm 0.04 \mathrm{nM}$ & $18 \mathrm{~s}$ & Present study \\
\hline
\end{tabular}

Table 5 The detected concentration of $\mathrm{Co}^{+2}$ ion in real environmental samples

\begin{tabular}{|c|c|c|c|c|}
\hline Sample & $\begin{array}{l}\text { Added } \mathrm{Co}^{+2} \text { ion con- } \\
\text { centration }(\mu \mathrm{M})\end{array}$ & $\begin{array}{l}{\text { Determined } \mathrm{Co}^{+2} \text { ion conc. }}^{\text {a }} \\
\text { by copolymer } \mathbf{8}_{\mathbf{e}} / \mathrm{GCE}(\mu \mathrm{M})\end{array}$ & Recovery $^{b}(\%)$ & $\operatorname{RSD}^{c}(\%)(n=3)$ \\
\hline \multirow{4}{*}{$\begin{array}{l}\text { Industrial } \\
\text { effluent }\end{array}$} & 0.01000 & 0.01007 & 100.7 & \multirow{4}{*}{0.49} \\
\hline & 0.01000 & 0.01006 & 100.6 & \\
\hline & 0.01000 & 0.00998 & 99.8 & \\
\hline & 0.0100 & 0.01085 & 108.5 & \\
\hline \multirow[t]{3}{*}{ Sea water } & 0.0100 & 0.01097 & 109.7 & \multirow[t]{3}{*}{0.88} \\
\hline & 0.0100 & 0.01104 & 110.4 & \\
\hline & 0.0100 & 0.01185 & 118.5 & \\
\hline \multirow[t]{2}{*}{ Tape water } & 0.0100 & 0.01186 & 118.6 & \multirow[t]{2}{*}{1.76} \\
\hline & 0.0100 & 0.01222 & 122.2 & \\
\hline
\end{tabular}

${ }^{\mathrm{a}}$ Mean of three repeated determination (signal to noise ratio 3 ) with copolymer $\mathbf{8}_{\mathbf{e}} /$ binder/GCE

${ }^{b}$ Concentration of $\mathrm{Co}^{+2}$ ion determined/concentration of $\mathrm{Co}^{+2}$ ion taken

${ }^{\mathrm{C}}$ Relative standard deviation value indicates precision among three repeated determinations was described this steady state current versus concentration relation and experimental data were distributed homogeneously around linear plot. Therefore, it should be noted that, $\mathrm{Co}^{+2}$ cationic sensor based on copolymer $\mathbf{8}_{\mathbf{e}} /$ binder/GCE can applied to detect $\mathrm{Co}^{+2}$ cation successively in aqueous medium by electrochemical method. The logarithm of calibration plot was also presented in the inset of Fig. 9c, where the linearity was observed. Furthermore, a control experiment has been performed and presented in Fig. $9 \mathrm{~d}$ with various modification of GCE such as bare-GCE, Nafion/GCE and copolymer $\left(\mathbf{8}_{\mathbf{e}}\right) / \mathrm{Nafion} / \mathrm{GCE}$. It was clearly observed that the current response was significantly found higher on $\mathrm{Co}^{+2}$ detection with copolymer $\left(\mathbf{8}_{\mathbf{e}}\right) / \mathrm{Nafion} /$ GCE compared with only bare-GCE and Nafion/GCE electrode probes. As it was previously described in Fig. $8 \mathrm{~b}$, the response time was around $18.0 \mathrm{~s}$, that means, this time was necessary to find steady state detection of $\mathrm{Co}^{+2}$ ion in phosphate buffer system with $\mathrm{pH}$ value of 7.0. Thus, with this study, the data recording time was set as $20.0 \mathrm{~s}$. Table 4 showed the comparison of sensor performances based on various modified electrodes [48-51, 58-67]. Therefore, the proposed cationic sensor based on copolymer $\mathbf{8}_{\mathbf{e}}$ /binder/ GCE was very simple and reliable for selective detection 
of $\mathrm{Co}^{+2}$ ion in neutral buffer medium for the safety of environment.

\subsubsection{Real sample analysis}

To find out the validity of copolymer $\mathbf{8}_{\mathbf{e}} /$ binder/GCE sensor, it was very important to test the proposed $\mathrm{Co}^{+2}$ cationic sensor in real environmental samples by electrochemical approach. The applicability of $\mathrm{Co}^{+2}$ cationic sensor has been carried out in various environmental samples, which were collected from different sources such as sea water, tap water and industrial waste effluents. The resulted data were represented in Table 5 and found very satisfactory.

\section{Conclusion}

A novel class of hybrid poly(ether-arylidene-ethersulphone)s and their corresponding copolymers has been successfully synthesized through solution polycondensation technique. 4,4'-thioxo-bis (4"'chlorobenzylideneimino-phenylene) was prepared as a leading monomer prior the polymerization process. The other required monomers, and precursors were also synthesized and their chemical framework were established by right elemental and spectral analyses. Alongside, a hybrid diphenyl(ether-sulphone-ether) compound was synthesized as a model compound and its structure was also investigated by both elemental and spectral data. The synthesized category of sulphone based polymers and copolymers has significantly high solubility character and viscosity as well. The average molecular weight for tested copolymers is somewhat higher than that measured for the tested polymers. XRD diffractograms of polymers $\mathbf{7}_{\mathrm{a}, \mathrm{c}}$ and copolymers $\mathbf{8}_{\mathrm{b}, \mathrm{f}}$ show high degree of crystallinity. Polymer $\mathbf{7}_{\mathbf{b}}$ and copolymer $\mathbf{8}_{\mathbf{a}}$ have lower thermally stable values at $\mathrm{T}_{40}$ and $\mathrm{T}_{50}$. Whereas, copolymers $\mathbf{8}_{\mathbf{d}, \mathbf{e}}$ display high thermal stability in the same range. The PDT thermal stabilities of these polymers and copolymers are in the order $\mathbf{7}_{d}>\mathbf{8}_{a}>\mathbf{7}_{b}>\mathbf{8}_{e}>\mathbf{8}_{b}>\mathbf{8}_{d}$. EWL values are ranged between 29 and $41 \%$ for all tested samples. The $\mathrm{Co}^{+2}$ cationic sensor based on copolymer $\mathbf{8}_{\mathrm{e}}$ /binder/GCE is performed well by electrochemical approach in terms of good sensitivity, lower detection limit, shorter response time, real sample validation, and a broader linear dynamic range $(1.0 \mathrm{nM} \sim 0.01 \mathrm{M})$. The proposed cationic sensor is excellent to detect selective $\mathrm{Co}^{+2}$ ion in various environmental real samples. Therefore, the $\mathrm{Co}^{+2}$ cationic sensor might be a reliable and effective sensor to detect selective $\mathrm{Co}^{+2}$ ion for the safety of environmental and healthcare sector in a broad scales.

\section{Compliance with ethical standards}

Conflict of interest The authors declare that there is no conflict of interest.

\section{References}

1. Kociołek-Balawejder E, Stanisławska E, Jacukowicz-Sobala I (2016) Synthesis and characterization of CuO-loaded macroreticular anion exchange hybrid polymer. React Funct Polym 100:107-115

2. Leitsch EK, Heath WH, Torkelson JM (2016) Polyurethane/polyhydroxyurethane hybrid polymers and their applications as adhesive bonding agents. Int J Adhes Adhes 64:1-8

3. Liu Y, Lv C, Ding J, Qian P, Zhang X, Yu Y, Ye S, Chen Y (2016) The use of the organic-inorganic hybrid polymer $\mathrm{Al}(\mathrm{OH}) 3-$ polyacrylamide to flocculate particles in the cyanide tailing suspensions. Miner Eng 89:108-117

4. Gopi V, Varma SJ, Kumar MVM, Prathapan S, Jayalekshmi S, Joseph R (2016) Semiconducting thienylene-biphenylenevinylene hybrid polymers: synthesis, characterization and application prospects in polymer LEDs. Dye Pigment 126:303-312

5. Ullah A, Ullah S, Khan G, Shah SM, Hussain Z, Muhammad S, Siddiq M, Hussain H (2016) Water soluble polyhedral oligomeric silsesquioxane based amphiphilic hybrid polymers: synthesis, self-assembly, and applications. Eur Polym J 75:67-92

6. Jacukowicz-Sobala I, Drabent K, Kociołek-Balawejder E (2015) Evaluation of ferromagnetic hybrid polymers obtained using cation exchangers. Mater Chem Phys 161:107-115

7. Coan T, Barroso GS, Machado RAF, de Souza FS, Spinelli A, Motz G (2015) A novel organic-inorganic PMMA/polysilazane hybrid polymer for corrosion protection. Prog Org Coat 89:220-230

8. Yana H, Wang M, Han Y, Qiao F, Row KH (2014) Hybrid molecularly imprinted polymers synthesized with 3-aminopropyltriethoxysilane-methacrylic acid monomer for miniaturized solidphase extraction: a new and economical sample preparation strategy for determination of acyclovir in urine. J Chromatogr A 1346:16-24

9. Choi J-K, Dung MX, Jeong H-D (2014) Novel synthesis of covalently linked silicon quantum dotepolystyrene hybrid materials: silicon quantum dotepolystyrene polymers of tunable refractive index. Mater Chem Phys 148:463-472

10. Hussein MA, Marwani HM, Alamry KhA, Asiri AM, El-Daly SA (2014) Surface selectivity competition of newly synthesized polyarylidene(keto-amine) polymers toward different metal ions. J Appl Polym Sci 131(1-10):40873

11. Abbady MA, Aly KI, Mahgoub SA, Hussein MA (2005) New polymer synthesis part 15 . Synthesis and characterization of new polyketoamine polymers containing ether and thioether linkage in the main chain. J Polym Int 54:1512-1523

12. Aly Kl, Abbady MA, Mahgoub SA, Hussein MA (2002) New polymer synthesis part 14 . Synthesis and properties of some new polyketoamine polymers containing cycloalkanone moieties in the main chain. J Polym Int 51:125-133

13. Graziola F, Girardi F, Di Maggio R, Callone E, Miorin E, Negri M, Müller K, Gross S (2012) Three-components organic-inorganic hybrid materials as protective coatings for wood: optimisation, synthesis, and characterization. Prog Org Coat 74:479-490

14. Wang S, Alagha L, Xu Z (2014) Adsorption of organic-inorganic hybrid polymers on kaolin from aqueous solutions. Colloids Surf A 453:13-20

15. Yuan W, Shen T, Liu X, Ren J (2013) Star-shaped inorganicorganic hybrid polymers with polyhedral oligomeric 
silsesquioxane core: synthesis, self-assembly and tunable thermoresponse. Mater Lett 111:9-12

16. Lebeau B, Sanchez C (1999) Sol-gel derived hybrid inorganicorganicnanocomposites for optics. Curr. Opin. Solid State Materials Science 4:11-23

17. Aly KI, Hussein MA (2015) Synthesis, characterization and corrosion inhibitive properties of new thiazole based polyamides containing diarylidenecyclohexanone moiety. Chin J Polym Sci 33:1-13

18. Aly KI, Hussein MA, Sayed MM (2013) Liquid crystalline polymers XII. Main chain thermotropic poly(arylidene-ether)s containing 4-tertiary-butyl-cyclohexanone moiety linked with polymethylene spacers. Liq Cryst 40:1570-1580

19. Hussein MA, Abdel-Rahman MA, Asiri AM, Alamry KhA, Aly KI (2012) Review on: liquid crystalline polyazomethines polymers. Basics, syntheses and characterization. Des Monomers Polym 15:431-463

20. Aly KI, Hussein MA (2010) New polymer syntheses, part 45: corrosion inhibition behavior of novel polyurea derivatives based on diarylidenecycloalkanone moieties in the polymers backbone. J Polym Res 17:607-620

21. Al-Muaikel NS, Aly KI, Hussein MA (2008) Synthesis, characterization and antimicrobial properties of new poly (ether-ketone)s and copoly(ether-ketone)s containing diarylidenecycloalkanone moieties in the main chain. J Appl Polym Sci 108:3138-3147

22. Aly Kl, Wahdan MH, Hussein MA (2009) New polymer syntheses, part 43: novel polyamides-based diarylidenecyclopentanone: synthesis, characterization, and corrosion inhibition behavior. J Appl Polym Sci 112:513-523

23. Hamciuc C, Hamciuc E (2010) Functional polymeric materials designed for hi-tech applications. In: Nechifor M (ed) Transworld Research Network, Kerala, India, pp 21-41

24. Hedrick J, Twieg R, Matray T, Carter K (1993) Heterocycle-activated aromatic nucleophilic substitution: poly(aryl ether phenylquinoxalines). Macromolecules 26:4833-4839

25. Aly Kl, Abbady MA, Mahgoub SA, Hussein MA (2007) Liquid crystalline polymers IX main chain thermotropic poly(azomethineether)s containing thiazole moiety linked with polymethylene spacers. J Express Polym Lett 1:197-207

26. Hedrick JL, Labadie JW (1990) Poly(aryl ether-phenylquinoxalines). Macromolecules 23:1561-1568

27. Bottino FA, Di Pasquale G (2001) Synthesis, characterization, and study of the thermal properties of new poly(arylene ether 1,3,4-oxadiazole)s. Macromolecules 34:33-37

28. Bruma M (1997) Polyphenylquinoxalines. In: Olabisi O (ed) Handbook of thermoplastics. Marcel Dekker, New York, pp 771-798

29. Zhang Q, Zhang S, Bi W (2011) Synthesis and properties of amphiphilic poly(ethylene oxide)-grafted cardo poly(aryl ether sulfone) copolymers. Polymer 52:5471-5478

30. Chain-Shu H, Ling-Bar Ch (1993) Synthesis and characterization of block copolymers of polyether sulfone with liquid crystalline polyesters. Mater Chem Phys 34:28-34

31. Chang Y-M, Hs C-S, Liu M-Ch (1996) Synthesis and characterization of segmented copolymers of aromatic polyether sulfone and thermotropic liquid crystalline poly(oxy- 1,4-phenylenecarbonyl-co-oxy-2,6-naphthaloyl). Mater Chem Phys 43:250-255

32. Auman BC, Percec V (1988) Synthesis and characterization of segmented copolymers of aromatic polyether sulphone and a thermotropic liquid crystalline polyester. Polymer 29:938-949

33. Na YJ, Choi YW, You GR, Kim C (2016) A novel selective colorimetric chemosensor for cobalt ions in a near perfect aqueous solution. Sens Actuators, B 223:234-240

34. Ahuja DK, Gavalas VG, Bachas LG, Bhattacharyya D (2004) Aqueous-phase dechlorination of toxic chloroethylenes by vitamin B12 cobalt center: conventional and polypyrrole film-based electrochemical studies. Ind Eng Chem Res 43:1049
35. Marques HM, Brown KL (2002) Molecular mechanics and molecular dynamics simulations of porphyrins, metalloporphyrins, heme proteins and cobalt corrinoids. Coord Chem Rev 225:123

36. Awual MR, Yaita T, Okamoto Y (2014) A novel ligand based dual conjugate adsorbent for cobalt (II) and copper (II) ions capturing from water. Sens Actuators, B 203:71-80

37. Ali TA, Mohamed GG, Omar MM, Hanafy NM (2017) Construction and performance characteristics of chemically modified carbon paste electrodes for the selective determination of $\mathrm{Co}$ (II) ions in water samples. J Ind Eng Chem 47:102-111

38. Manohar DM, Noeline BF, Anirudhan TS (2006) Adsorption performance of Al-pillared bentonite clay for the removal of cobalt(II) from aqueous phase. Appl Clay Sci 31:194-206

39. Chi B, Li J, Yang X, Gong Y, Wang N (2005) Deposition of Ni-Co by cyclic voltammetry method and its electro catalytic properties for oxygen evolution reaction. Int J Hydrog Energy 30:29-34

40. Rao KS, Balaji T, Rao TP, Naidu GRK (2002) Determination of iron, cobalt, nickel, manganese, zinc, copper, cadmium and lead in human hair by inductively coupled plasma-atomic emission spectrometry. Spectrochim Acta B At Spectrosc 57:1333-1338

41. Minami T, Atsumi K, Ueda J (2003) Determination of cobalt and nickel by graphite furnace atomic absorption spectrometry after co-precipitation with scandium hydroxide. Anal Sci 19:313-315

42. Shahat A, Awual MR, Naushad M (2015) Functional ligand anchored nanomaterial based facial adsorbent for cobalt(II) detection and removal from water samples. Chem Eng J 271:155-163

43. Rahman MM, Khan SB, Asiri AM, Quisti A (2013) Selective detection of toxic $\mathrm{Pb}$ (II) ions based on wet-chemically prepared nanosheets integrated $\mathrm{CuO}-\mathrm{ZnO}$ nanocomposites. Compos $\mathrm{B}$ Eng 54:215-223

44. Abd-Alla MA, Kandeel MM, Aly Kl, Hammam AS (1990) Arylidene polymers. Il synthesis and characterization of some new polyesters of diarylidenecyclopentanone. J Macromol Sci Chem 27:523-538

45. Abd-Alla MA, Aly KI, Hammam AS (1989) Arylidene polymers IV. Synthesis, characterization and morphology of new polyesters of diarylidenecyclohexanone. High Perform Polym 1:223-237

46. Marin L, Cozan V, Bruma M, Grigoras VC (2006) Synthesis and thermal behavior of new poly(azomethine-ether). Eur Polym $J$ 42:1173-1182

47. Aly KI, Khalaf AA (2000) New polymer syntheses. IX. Synthesis and properties of new conducting polyazomethine polymers containing main chain cycloalkanone and pyridine moieties. J Appl Polym Sci 77:1218-1229

48. Ryu KY, Lee SY, Park DY, Kim SY, Kim C (2017) A novel colorimetric chemosensor for detection of $\mathrm{Co}^{2+}$ and $\mathrm{S}^{2-}$ in an aqueous environment. Sens Actuators B Chem 242:792-800

49. Na YJ, Choi YW, You GR, Kim C (2016) A novel selective colorimetric chemosensor for cobalt ions in a near perfect aqueous solution. Sens Actuators B Chem 223:234-240

50. Lee SY, Lee JJ, Bok KH, Kim SY, Kim C (2016) Highly selective and sensitive colorimetric chemosensor for detection of $\mathrm{Co}^{2+}$ in a near-perfect aqueous solution. RSC Adv 6:28081-28088

51. Lee JJ, Choi YW, You GR, Lee SY, Kim C (2015) A phthalazinebased two-in-one chromogenic receptor for detecting $\mathrm{Co}^{2+}$ and $\mathrm{Cu}^{2+}$ in an aqueous environment. Dalton Trans 44:13305-13314

52. Sheikh TA, Arshad MN, Asiri AM, Rahman MM (2018) Development of selective and sensitive $\mathrm{Ga}^{3+}$ sensor for environmental safety: a comparative study between cyclohexane and aromatic bis-sulphonamides fabricated glassy carbon electrodes. New J Chem 42:13589-13601

53. El-Shishtawy RM, Al-Ghamdi HA, Alam MM, Al-Amshany ZM, Asiri AM, Rahman MM (2018) Development of $\mathrm{Cd}^{2+}$ sensor based on BZNA/Nafion/glassy carbon electrode by electrochemical approach. Chem Eng J 352:225-231 
54. Rahman MM, Hussein MA, Aly KI, Asiri AM (2018) Thermally stable hybrid polyarylidene(azomethine-ether)s polymers (PAAP): an ultrasensitive arsenic(III) sensor approach. Des Monomers Polym 21:82-89

55. Rahman MM, Sheikh TA, El-Shishtawy RM, Arshad MN, Al-Zahrani FAM, Asiri AM (2018) Fabrication of $\mathrm{Sb}^{3+}$ sensor based on 1,1'-(-(naphthalene-2,3-diylbis(azanylylidene))bis (methanylylidene))bis(naphthalen-2-ol)/Nafion/glassy carbon electrode assembly by electrochemical approach. RSC Adv 8:19754-19764

56. Masoumi A, Gargari MS, Mahmoudi G, Miroslaw B, Therrien B, Abedi M, Hazendonk P (2015) Structural diversity in mercury (II) coordination complexes with asymmetrical hydrazone-based ligands derived from pyridine. J Mol Struct 1088:64

57. Shimizu Y, Furuta Y (1998) An opto-electrochemical phosphateion sensor using a cobalt-oxide thin-film electrode. Solid State Ion 113:241-245

58. Kumar P, Shim YB (2009) A novel cobalt(II)-selective potentiometric sensor based on p-(4-n-butylphenylazo)calix[4]arene. Talanta 77:1057-1062

59. Gupta VK, Ganjali MR, Norouzi P, Khani H, Nayak A, Agarwal S (2011) Electrochemical analysis of some toxic metals by ionselective electrodes. Crit Rev Anal Chem 41:282-313

60. Aqlan FM, Alam MM, Saleh TS, Asiri AM, Uddin J, Rahman MM (2019) Synthesis of novel pyrazole incorporating coumarin moiety (PC) based electrochemical sensor for the selective and sensitive $\mathrm{Co}^{2+}$ detection. New J Chem 43:12331-12339

61. Awual MR, Hasan MM, Islam A, Asiri AM, Rahman MM (2020) Optimization of an innovative composited material for effective monitoring and removal of cobalt(II) from wastewater. J Mol Liq 298:112035

62. Katowah DF, Rahman MM, Hussein MA, Sobahi TR, Gabal MA, Alam MM, Asiri AM (2019) Ternary nanocomposite based
poly(pyrrole-co-O-toluidine), cobalt ferrite and decorated chitosan as a selective $\mathrm{Co}^{2+}$ cationic sensor. Compos Part B Eng $175: 107175$

63. Awual MR, Alharthi NH, Hasan MM, Karim MR, Islam A, Znad $H$, Hossain MA, Halim M, Rahman MM, Khaleque MA (2017) Inorganic-organic based novel nano-conjugate material for effective cobalt(II) ions capturing from wastewater. Chem Eng J 324:130-139

64. Hussain MM, Asiri AM, Arshad MN, Rahman MM (2018) Development of selective $\mathrm{Co}^{2+}$ ionic sensor based on various derivatives of benzenesulfonohydrazide (BSH) compounds: an electrochemical approach. Chem Eng J 339:133-143

65. Khan SB, Asiri AM, Rahman MM, Marwani HM, Alamry KA (2015) Evaluation of cerium doped tin oxide nanoparticles as a sensitive sensor for selective detection and extraction of cobalt. Phys E 70:203-209

66. Rahman MM, Khan SB, Marwani HM, Asiri AM (2014) Selective divalent cobalt ions detection using $\mathrm{Ag}_{2} \mathrm{O}_{3}-\mathrm{ZnO}$ nanocones by ICP-OES method for environmental remediation. PLoS One 9:e114084

67. Sheikh TA, Arshad MN, Rahman MM, Asiri AM, Alamry KA (2016) Development of highly efficient $\mathrm{Co} 2+$ ions sensor based on $N, N^{\prime}$-(ethane-1,2-diyl)bis(2,5-dimethoxybenzenesulfonamide) (EBDMBS) fabricated glassy carbon electrode. J Organomet Chem 822:53-61

Publisher's Note Springer Nature remains neutral with regard to jurisdictional claims in published maps and institutional affiliations. 